\title{
Long-term effectiveness and safety of transcatheter closure of patent foramen ovale compared with antithrombotic therapy alone: a meta-analysis of six randomised clinical trials and 3,560 patients with reconstructed time-to-event data
}

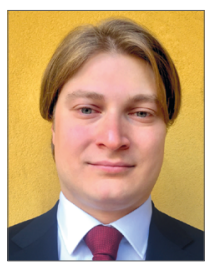

Daniele Giacoppo ${ }^{1,2,3 *}$, MD; Nicola Caronna ${ }^{3}, \mathrm{MD}$; Antonio H. Frangieh ${ }^{1,2}, \mathrm{MD}, \mathrm{MPH}$; Jonathan Michel ${ }^{1,2}, \mathrm{MBBS}$; Giuseppe Andò ${ }^{4}, \mathrm{MD}, \mathrm{PhD}$; Giuseppe Tarantini ${ }^{5}, \mathrm{MD}, \mathrm{PhD}$; Albert M. Kasel ${ }^{1,2}, \mathrm{MD}$; Davide Capodanno ${ }^{6,7}, \mathrm{MD}, \mathrm{PhD}$; Robert A. Byrne ${ }^{1,8}, \mathrm{MB}, \mathrm{BCh}, \mathrm{PhD}$

1. Deutsches Herzzentrum München, Technische Universität München, Munich, Germany; 2. Munich Structural Heart Institute, Munich, Germany; 3. Azienda Ospedaliero-Universitaria "Policlinico Giaccone”, University of Palermo, Palermo, Italy; 4. Azienda Ospedaliero-Universitaria "Policlinico Martino", University of Messina, Messina, Italy; 5. Department of Cardiac, Thoracic and Vascular Sciences, University of Padua, Padua, Italy; 6. Cardio-Thoracic-Vascular Department, Azienda Ospedaliera Universitaria "Policlinico-Vittorio Emanuele", Catania, Italy; 7. Department of General Surgery and MedicalSurgical Specialties, University of Catania, Catania, Italy; 8. DZHK (German Center for Cardiovascular Research), Partner Site Munich Heart Alliance, Munich, Germany

GUEST EDITOR: Alec Vahanian, MD, PhD; Department of Cardiology, Hôpital Bichat-Claude Bernard, and University Paris VII, Paris, France

This paper also includes supplementary data published online at: http://www.pcronline.com/eurointervention/141st_issue/154

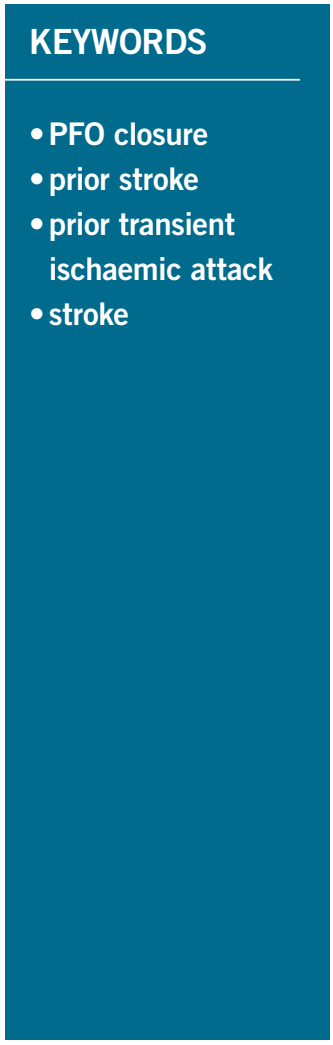

\section{Abstract}

Aims: Although three recent trials have shown a significant stroke risk reduction after tPFOc, the individual statistical power is limited and the impact on pooled evidence needs to be explored. We aimed to pool data from available randomised clinical trials (RCT) to assess whether tPFOc is more effective and safe than antithrombotic therapy alone (ATA).

Methods and results: Major electronic databases and tangential sources were searched. Six trials (3,560 patients) were identified. At a median follow-up of 3.6 (2.0-5.2) years (13,930 person-years), the risk of stroke was significantly lower after tPFOc compared with ATA (HR 0.28, 95\% CI: 0.12-0.64, p=0.003). Significant heterogeneity was detected $\left(\mathrm{I}^{2}=66.1 \%\right)$, although single trials did not significantly influence the results. Reconstructed time-to-event data revealed that $\mathrm{PFOc}$ benefits accrue after approximately one year and persist over time without significant variations (96.4\% versus $88.0 \%$; HR $0.25,95 \%$ CI: $0.09-0.66$, $\mathrm{p}=0.005$; NNT=11). Although results showed a greater benefit in patients $<45$ years old, male, and with substantial shunt, interaction between subgroups was not significant. Trial sequential analysis showed that accumulated evidence appeared to be sufficient. However, tPFOc did not confer protection against transient ischaemic attack (TIA; HR 0.69, 95\% CI: 0.31-1.54, $\mathrm{p}=0.365$ ) and a significant excess in the risk of atrial fibrillation was observed (OR 4.99, 95\% CI: 1.99-10.10, p<0.001), though generally early and transient. Major bleeding and migraine were comparable between treatments.

Conclusions: Compared with ATA, tPFOc significantly reduces the risk of stroke at long-term follow-up but no benefit is observed in terms of TIA. Atrial fibrillation is higher after tPFOc, though generally early and transient. The risks of major bleeding and migraine are comparable between the groups.

*Corresponding author: Deutsches Herzzentrum München, Lazarettstrasse 36, 80636 Munich, Germany.

E-mail: giacoppomd@gmail.com 


\section{Abbreviations}

ATA antithrombotic therapy alone

CI confidence interval

HR hazard ratio

NNT number needed to treat

OR odds ratio

PFO patent foramen ovale

RCT randomised clinical trials

tPFOc transcatheter patent foramen ovale closure

TIA transient ischaemic attack

\section{Introduction}

Patent foramen ovale (PFO) is associated with an increased risk of stroke as a result of paradoxical cerebral embolism ${ }^{1,2}$. Transcatheter $\mathrm{PFO}$ closure (tPFOc) is an attractive preventive approach but its effectiveness compared with antithrombotic therapy alone (ATA) has remained a matter of debate for a long time ${ }^{3,4}$. Indeed, early randomised clinical trials (RCT) did not prove a significant reduction in stroke compared with $\mathrm{ATA}^{4-7}$, although later a pooled analysis and observational data fostered a possible benefit of $\mathrm{PFOc}^{4,8,9}$. Currently, the European Stroke Organisation indicates tPFOc only in patients with cryptogenic stroke and PFO with high-risk features, while the American Heart Association/American Stroke Association guidelines consider $\mathrm{PFOc}$ a viable alternative to ATA only in patients with PFO and recurrent deep vein thrombosis ${ }^{10,11}$.

Recently, the results of the CLOSE, Gore REDUCE, and DEFENSE-PFO trials ${ }^{12-14}$ showed significant risk reductions in stroke after tPFOc. Because all of the existing trials have low statistical power to detect difference in stroke rates and questions on secondary efficacy and safety endpoints remain unanswered, an updated systematic review represents a relevant undertaking. The several meta-analyses on the topic published over time present (with mixed proportions) the following limitations: absence of one or more of the available RCT, biased selection of reports, evidence based mostly on observational studies, inappropriate definition of the risk by estimates not accounting for time, missing or incomplete assessment of the risk variation over time, insufficient exploration of the heterogeneity across trials and clinical subgroups, omitted quantification of statistical power of the accumulated evidence, and incomplete definition of the net benefit of $\mathrm{tPFOc}^{5,15-19}$.

Against this background, we aimed to provide an updated meta-analysis on $\mathrm{TPFOc}$ versus ATA to quantify the impact of the three newer trials, and to provide a proper description of risk variation in relation to time, and a critical assessment of the net benefit of tPFOc.

\section{Methods}

We conducted a frequentist pairwise meta-analysis in keeping with the recommendations of PRISMA (Supplementary Table 1) and the Cochrane Collaboration ${ }^{20,21}$. This meta-analysis was registered with PROSPERO (www.crd.york.ac.uk/prospero/; CRD42017081518).

\section{ELIGIBILITY CRITERIA AND LITERATURE SEARCH}

Three authors (N. Caronna, A.H. Frangieh, J. Michel) independently searched PubMed, Scopus, Web of Knowledge, ScienceDirect and Ovid electronic databases from the inception to 1 December 2017. No language restrictions or specific clinical subsets were imposed. A complementary search was performed by accessing major scientific websites with interest in the topic (www.clinicaltrials.gov, www.clinicaltrialresults.org, www.tctmd. com, www.pcronline.com, www.acc.org, www.heart.org) and screening of bibliographies of relevant reviews and book chapters. Duplicates due to the multiple-database search were removed. The retrieved data set was used for preliminary assessment of the feasibility of the meta-analysis and for qualitative definition of each of the included trials (Supplementary Appendix 1).

According to PRISMA recommendations ${ }^{20}$, after data extraction, performance of the statistical analysis, and manuscript drafting, a last search was made on 15 March 2018. The identification of an additional trial that met eligibility criteria required an update of the meta-analysis.

\section{ENDPOINTS}

The primary endpoint was stroke at the longest available followup. The secondary endpoints included transient ischaemic attack (TIA), atrial fibrillation, major bleeding and migraine at the longest available follow-up.

\section{DATA EXTRACTION}

Authors involved in the search (N. Caronna, A.H. Frangieh, J. Michel, D. Giacoppo) extracted trial-level qualitative and quantitative data. Trial-level risk estimates, incidences of events, and numbers of patients were exported for statistical analysis. Intention-to-treat analyses were considered. All the authors had full access to the data.

\section{STATISTICAL ANALYSIS}

Categorical variables are presented as proportions (counts) and were tested using the $\chi^{2}$ test. Continuous variables are presented as means (standard deviations) and were compared using the t-test or ANOVA. Within-trial and between-trial means and standard deviations were weighted.

According to original long-term time-to-event analyses, triallevel hazard ratios (HRs) and 95\% confidence intervals (CIs) were used for stroke and TIA. Pooled risk estimates were computed by fixed-effect and random-effects models with inverse variance weighting ${ }^{21,22}$. Risk distribution across trials was illustrated by forest plots with weighting according to a random-effects model ${ }^{21,22}$. The number needed to treat (NNT) was estimated as previously described for survival analysis ${ }^{22,23}$.

We assessed heterogeneity by using Cochran's $Q$ test with significance set at 0.10 , between-study variance $\tau^{2}$, and the $\mathrm{I}^{2}$ statistic ${ }^{21,22,24}$. $\mathrm{I}^{2}$ values $<25 \%$ expressed low heterogeneity, $25-50 \%$ moderate heterogeneity, and $>50 \%$ high heterogeneity ${ }^{24}$.

We reconstructed time-to-event data for the primary endpoint of stroke by extreme-magnification digitisation of the original 
high-quality Kaplan-Meier curves and then by modelling of retrieved spatial information along with numbers of events and numbers at risk for each time interval ${ }^{25,26}$. Additional information is provided in Supplementary Appendix 2. Retrieved data were used to carry out Kaplan-Meier analyses. According to a "one-stage" meta-analysis, a mixed-effect Cox proportional hazard regression model taking into account the original clustering of patients across trials was used to provide risk estimates alternative to those obtained by standard aggregate-data meta-analysis ${ }^{27}$. A "two-stage" meta-analysis with trial-level estimates according to Cox regression was also performed. Differences between treatments were compared by log-rank test.

A restricted maximum likelihood random-effects multiple-outcome meta-analysis was performed to provide a joint estimate of the risk of ischaemic stroke and TIA ${ }^{28}$. We decided to apply such a type of inference because it can provide estimates taking into account the correlation between outcomes and overcome missing values ("borrowing of strength") 28 .

Risks of atrial fibrillation, major bleeding and migraine between groups were expressed by odds ratios (ORs) and 95\% CIs, since these outcomes were not uniformly reported according to time-toevent analyses across trials and most of them occurred early.

Analyses were performed using R 3.4.1 (R Foundation for Statistical Computing, Vienna, Austria) and Stata 13 (StataCorp, College Station, TX, USA).

\section{SENSITIVITY AND SUBGROUP ANALYSES}

The influence of individual trials on pooled estimates and heterogeneity was explored by removing each one at a time ("leave-one-out") 29.

Time-to-event landmark analyses were performed to compare the distributions of the events between groups from enrolment to two-year follow-up and from two years after enrolment to maximum available follow-up. In addition, after excluding trials having shorter follow-up, we assessed the risk of stroke between groups at five years to remove possible influences of trials designed to assess outcomes at earlier time points and mitigate the impact of very late follow-up variations across trials.

A cumulative meta-analysis was conducted to inspect the variations after addition of each trial in a chronological order and an O'Brien-Fleming monitoring boundary by using the Lan-DeMets alpha spending function approach ("trial sequential analysis") was computed to exclude spurious effects ${ }^{30}$. In addition, pooled effects of earlier and newer trials were compared to quantify the contrast between early and recent results.

Consistency of main results was assessed across the subgroups of age $<45$ versus $\geq 45$ years, male versus female, and substantial versus non-substantial shunt according to large or mild-to-moderate transit of microbubbles, respectively. Interaction between effects was assessed with significance set at 0.05 .

Finally, the risk of TIA was also assessed by using OR according to the reported number of events.

\section{BIAS ASSESSMENT}

Trial-level qualitative assessment was performed by using the Cochrane Collaboration tool ${ }^{21}$, and the robustness of the meta-analysis conclusions was defined according to GRADE ${ }^{31}$. Further specifications on the two tools are reported in Supplementary Appendix 2.

\section{Results}

The search process is illustrated in Supplementary Figure 1 and details of the strategy applied are shown in Supplementary Table 2.

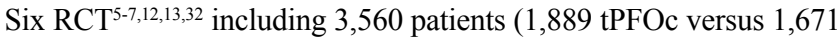
ATA) were included in the meta-analysis. The main characteristics are reported in Table 1, while eligibility criteria are listed in Supplementary Table 3. Baseline characteristics were balanced between groups (Supplementary Table 4), though there were differences across trials (Supplementary Table 5). Overall, the included patients were middle-aged adults $(45.3 \pm 9.9$ years $)$, with similar distribution between genders and low cardiovascular risk profile. Almost all patients had a recent cryptogenic stroke as qualifying event and frequently had large shunting. Devices and ATA regimens across trials are reported in Table 1 and Supplementary Table 6.

\section{STROKE}

At a median follow-up time of 3.6 [2.0-5.2] years, 116 events occurred, 37 after tPFOc and 79 after ATA. Regardless of the model applied, the risk of stroke was significantly lower after tPFOc compared with ATA (HR 0.28, 95\% CI: 0.12-0.64, $\mathrm{p}=0.003$ ) (Figure 1). The relative weight of trials was balanced

\begin{tabular}{|c|c|c|}
\hline Trial & Closure & Medical \\
\hline CLOSURE I & $12 / 447$ & $13 / 462$ \\
\hline PC & $1 / 204$ & $7 / 210$ \\
\hline RESPECT & $18 / 499$ & $28 / 481$ \\
\hline CLOSE & $0 / 238$ & $14 / 235$ \\
\hline Gore REDUCE & $6 / 441$ & $12 / 223$ \\
\hline DEFENSE-PFO & & \\
\hline & $37 / 1,889$ & $79 / 1,671$ \\
\hline \\
\hline \multicolumn{3}{|c|}{$\begin{array}{l}\text { Random-effects model } \\
Q=14.766, p=0.011, \tau^{2}=0.611, l^{2}=66.1 \%\end{array}$} \\
\hline
\end{tabular}

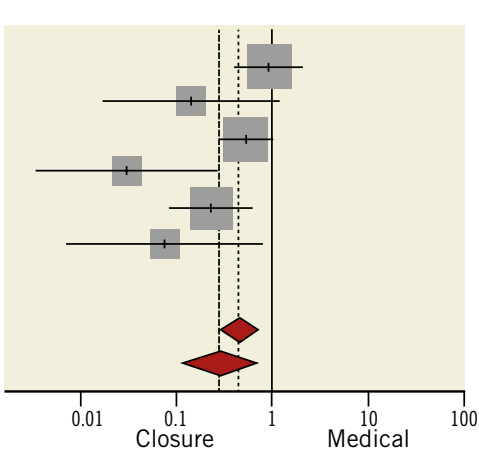

HR [95\% Cl]

$0.90[0.41,1.98]$

$0.14[0.02,1.15]$

$0.55[0.31,1.00]$

$0.03[0.00,0.26]$

$0.23[0.09,0.62]$

$0.07[0.00,0.75]$

$0.44[0.29,0.66]$

$0.28[0.12,0.64]$
Weight

$23.6 \%$

$10.4 \%$

$26.0 \%$

$10.0 \%$

$21.1 \%$

$9.0 \%$

Figure 1. Comparison between $P F O c$ and ATA at the longest available follow-up. 
Table 1. Main characteristics of included RCT.

\begin{tabular}{|c|c|c|c|c|c|c|}
\hline & CLOSURE I & PC & RESPECT & CLOSE & Gore REDUCE & DEFENSE-PFO \\
\hline Masking & Open-label & Open-label & Open-label & Open-label & Open-label & Open-label \\
\hline Design & Superioritya,b & Superiority ${ }^{b}$ & Superiorityb & Superiority ${ }^{\mathrm{a}}$ & Superiority & Superiority \\
\hline Randomisation & $1: 1$ & $1: 1$ & $1: 1$ & $1: 1: 1^{c}$ & $2: 1$ & $1: 1$ \\
\hline Centres & 87 & 29 & 69 & 34 & 63 & 2 \\
\hline Region & USA and Canada & $\begin{array}{l}\text { Switzerland, Germany, } \\
\text { Austria, Belgium, } \\
\text { Poland, Slovakia, United } \\
\text { Kingdom, Australia, } \\
\text { Canada, Brazil }\end{array}$ & USA and Canada & France and Germany & $\begin{array}{l}\text { USA, Canada, Denmark, } \\
\text { Finland, Sweden, United } \\
\text { Kingdom }\end{array}$ & South Korea \\
\hline Duration & June $2003-0$ ct 2008 & Feb 2000-Feb 2009 & Aug 2003-Dec 2011 & Dec 2008-Dec 2016 & Dec 2008-Feb 2015 & June 2011-0ct 2017 \\
\hline Adjudication & Blinded & Blinded & Blinded & Blinded & Blinded & Not specified \\
\hline Registration & NCT00201461 & NCT00166257 & NCT00465270 & NCT00562289 & NCT00738894 & NCT01550588 \\
\hline Protocol & Published & Published & Published & Published & Published & Not available \\
\hline Sponsor & NMT Medical & St. Jude Medical & St. Jude Medical & French Ministry of Health & W.L. Gore and Associates & Research Foundation \\
\hline Qualifying event & $\begin{array}{c}\text { TIA or ischaemic stroke } \\
<180 \text { days }\end{array}$ & $\begin{array}{c}\text { TIA with brain infarct at } \\
\text { imaging or ischaemic } \\
\text { stroke or extra-cranial } \\
\text { embolism }\end{array}$ & $\begin{array}{l}\text { Ischaemic stroke } \\
<270 \text { days }\end{array}$ & $\begin{array}{l}\text { Ischaemic stroke } \\
<180 \text { days }\end{array}$ & $\begin{array}{l}\text { TIA with new brain infarct } \\
\text { at imaging and ischaemic } \\
\text { stroke }<180 \text { days }\end{array}$ & $\begin{array}{l}\text { Ischaemic stroke } \\
<180 \text { days }\end{array}$ \\
\hline $\begin{array}{l}\text { Patients total } \\
\text { (device/medical) }\end{array}$ & $909(447 / 462)$ & $414(204 / 210)$ & $980(499 / 481)$ & $473(238 / 235)$ & $664(441 / 223)$ & $120(60 / 60)$ \\
\hline Device type & $\begin{array}{c}\text { STARFlex septal occluder } \\
(100 \%)\end{array}$ & $\begin{array}{l}\text { AMPLATZER PF0 } \\
\text { Occluder (100\%) }\end{array}$ & $\begin{array}{c}\text { AMPLATZER PFO Occluder } \\
(100 \%)\end{array}$ & \begin{tabular}{|l|} 
- AMPLATZER PF0 \\
Occluder (51.5\%) \\
- Intrasept PF0 occluder \\
(13.2\%) \\
- Premere $(9.4 \%)$ \\
- STARFlex septal \\
occluder (8.9\%) \\
- AMPLATZER Cribriform \\
Occluder (6.4\%) \\
- Figulla Flex II PF0 \\
occluder $(6.4 \%)$ \\
- Other device (4.3\%) \\
\end{tabular} & $\begin{array}{l}\text { - HELEX septal occluder } \\
\text { (38.7\%) } \\
\text { - Cardioform septal } \\
\text { occluder }(61.3 \%)\end{array}$ & $\begin{array}{l}\text { AMPLATZER PFO } \\
\text { Occluder (100\%) }\end{array}$ \\
\hline Primary endpoint & $\begin{array}{c}\text { Stroke or TIA, any-cause } \\
\text { death within } 30 \text { days, or } \\
\text { neurological death } \\
\text { between } 30 \text { days and } \\
2 \text { years }\end{array}$ & $\begin{array}{l}\text { Stroke, TIA, peripheral } \\
\text { embolism, or death }\end{array}$ & $\begin{array}{l}\text { Stroke, TIA, early } \\
\text { any-cause death or } \\
\text { neurological death }\end{array}$ & Stroke & $\begin{array}{l}\text { Stroke or new lesion } \\
>3 \mathrm{~mm}^{\mathrm{d}}\end{array}$ & $\begin{array}{l}\text { Stroke, vascular death, } \\
\text { TIMI major bleeding }\end{array}$ \\
\hline Follow-upe & $2.0[1.5-2.0]$ & $4.9[3.5-5.0]$ & $5.9[4.2-8.0]$ & $5.6[3.8-7.1]$ & $3.2[2.2-4.8]$ & $2.8[0.9-4.1]^{\dagger}$ \\
\hline $\begin{array}{l}\text { Person-years total } \\
\text { (device/medical) }\end{array}$ & $1,593(798 / 795)$ & $1,655(841 / 814)$ & $5,688(3,080 / 2,608)$ & $2,572(1,338 / 1,234)$ & $2,232(1,529 / 703)$ & $190(97 / 93)^{f}$ \\
\hline \multicolumn{7}{|c|}{ 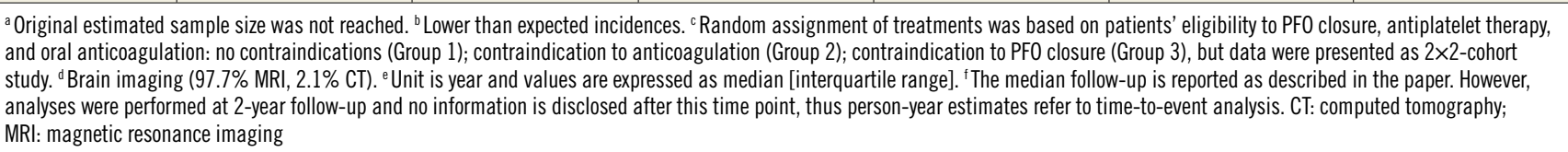 } \\
\hline
\end{tabular}

overall. However, a high degree of heterogeneity was observed $\left(\mathrm{I}^{2}=66.1 \%\right)$, reflecting the different magnitude of trial-level effects and $95 \%$ CIs rather than direction. Indeed, all point estimates were to the left of the null: the CLOSURE I trial ${ }^{5}$ showed no difference between strategies, the PC and RESPECT trials ${ }^{6,7,32}$ showed a numerical benefit of the interventional treatment, while the CLOSE and Gore REDUCE trials ${ }^{12,13}$ showed a significant risk reduction after tPFOc. Regardless of the model applied, no single trial could significantly influence pooled estimates (Figure 2) and between-trial heterogeneity remained high in any case.

Kaplan-Meier curves showed that difference between treatments emerged after approximately one year (Figure 3). The survival free from stroke at the maximum available follow-up $(13,930$ person-years) was $96.4 \%$ after tPFOc (7,683 person-years) and $88.0 \%$ after ATA (6,247 person-years). The annualised incidence of stroke was $0.48 / 100$ person-years after tPFOc and $1.26 / 100$ person-years after ATA. The meta-analysis of reconstructed time-to-event data provided results consistent with aggregate-data meta-analysis (HR $0.25,95 \% \mathrm{CI}: 0.09-0.66, \mathrm{p}=0.005)$. It was estimated that approximately 11 patients needed to undergo PFO closure to prevent one stroke as compared with ATA (NNT 11.3, 95\% CI: 9.2-25.6). The landmark analysis showed uniform distributions over time, and risk estimates by "one-stage" meta-analyses were consistent with "two-stage" meta-analyses (Figure 4). 
Trial

Omitting CLOSURE I

Omitting PC

Omitting RESPECT

Omitting CLOSE

Omitting Gore REDUCE

Omitting DEFENSE-PFO

Fixed-effect model

Trial

Omitting CLOSURE I

Omitting PC

Omitting RESPECT

Omitting CLOSE

Omitting Gore REDUCE

Omitting DEFENSE-PFO

Random-effects model
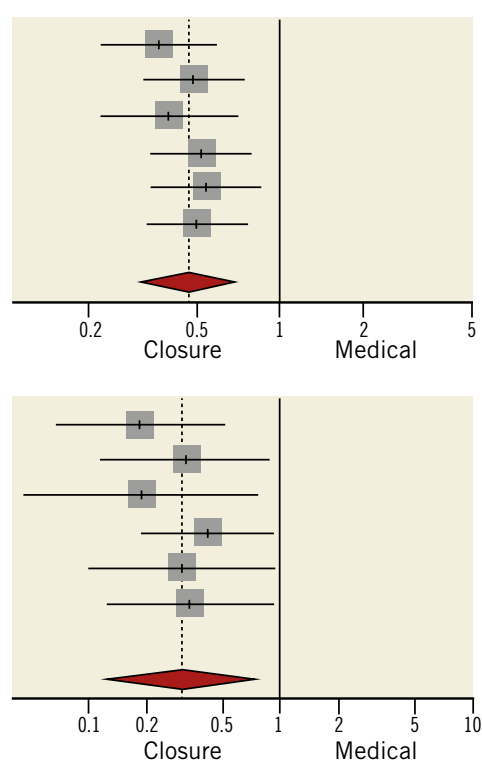

HR [95\% Cl] p-value

$0.34[0.21,0.54]<0.0001$

$0.46[0.30,0.69]<0.001$

$0.36[0.21,0.62]<0.001$

$0.48[0.32,0.73] \quad 0.001$

$0.50[0.32,0.78] \quad 0.002$

$0.46[0.31,0.70]<0.001$

$0.44[0.29,0.66] \quad<0.001$

HR [95\% CI] $\quad p$-value $\left.\quad \tau^{2} \quad\right|^{2}$

$\begin{array}{llll}0.19[0.07,0.51] & 0.001 & 0.690 & 61.7\end{array}$

$\begin{array}{llll}0.30[0.12,0.74] & 0.009 & 0.645 & 70.6\end{array}$

$\begin{array}{llll}0.19[0.06,0.64] & 0.007 & 1.195 & 70.7\end{array}$

$\begin{array}{llll}0.39[0.19,0.80] & 0.010 & 0.310 & 53.6\end{array}$

$\begin{array}{llll}0.28[0.10,0.76] & 0.013 & 0.775 & 68.7\end{array}$

$\begin{array}{llll}0.32[0.14,0.76] & 0.009 & 0.559 & 67.8\end{array}$

$\begin{array}{llll}0.28[0.12,0.64] & 0.003 & 0.611 & 66.1\end{array}$

Figure 2. Influence analysis.

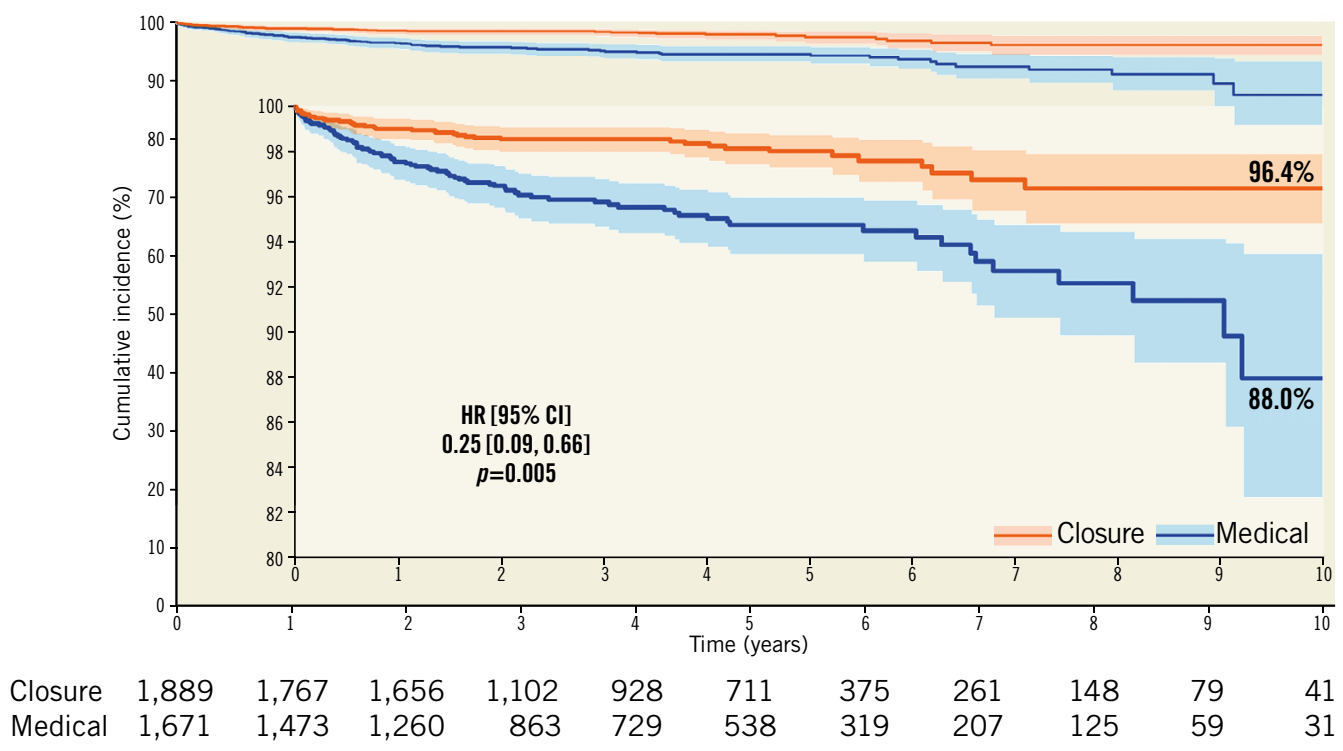

Figure 3. Survival free from stroke.

$\begin{array}{lcc}\text { Trial } & \text { Closure } & \text { Medical } \\ \text { CLOSURE I } & 1 / 447 & 3 / 462 \\ \text { PC } & 5 / 204 & 5 / 214 \\ \text { RESPECT } & 12 / 499 & 7 / 481 \\ \text { CLOSE } & 2 / 238 & 1 / 235 \\ \text { Gore REDUCE } & 3 / 441 & 1 / 223 \\ & \mathbf{2 3 / 1 , 8 2 9} & \mathbf{1 7 / 1 , 6 1 5}\end{array}$

Fixed-effect model Random-effects model $Q=0.417, p=0.761, \tau^{2}=0, I^{2}=0 \%$

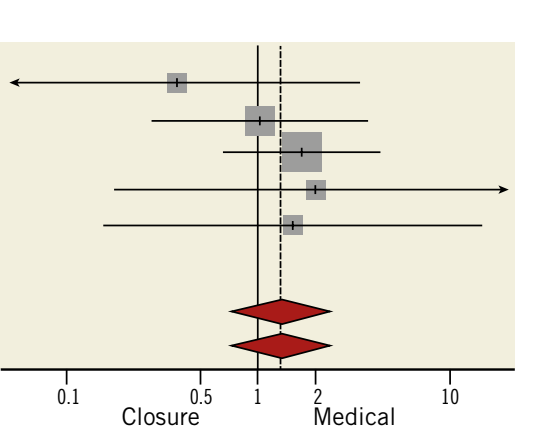

OR [95\% Cl] Weight

$0.34[0.04,3.31] \quad 8.4 \%$

$1.03[0.29,3.61] \quad 27.3 \%$

$1.67[0.65,4.27] \quad 48.6 \%$

$1.98[0.18,22.02] \quad 7.4 \%$

$1.52[0.16,14.70] 8.3 \%$

$1.29[0.67,2.48] \quad p=0.449$ $1.29[0.67,2.48] \quad p=0.449$

Figure 4. Landmark analysis. The risk estimates within Kaplan-Meier graphs are derived from mixed-effects Cox proportional hazards regression accounting for the original clustering of patients ("one-stage"). The forest plots illustrate sensitivity analyses according to standard Cox proportional hazards regression and subsequent combination of trial-level outcomes by fixed-effect or random-effects models ("two-stage"). 
The definition of stroke showed acceptable consistency across trials (Supplementary Table 7). Events, events/100 person-years, and Kaplan-Meier estimates across trials and time points are reported in Supplementary Table 8.

With the aim of excluding investigations implying outdated and potentially ineffective devices and including only trials achieving very long-term data, we excluded the CLOSURE I and DEFENSEPFO trials ${ }^{5,14}$. At five-year follow-up, no significant changes in the main conclusion were noted regardless of the method applied ("one-stage", mixed-effects Cox regression: HR 0.22, 95\% CI: 0.09-0.54, p=0.001; "two-stage" random-effects: HR 0.23, 95\% CI: $0.09-0.58, \mathrm{p}=0.002$ ) (Figure 5). Results by including all trials were consistent (Supplementary Table 8).

Trial sequential analysis was performed to exclude spurious results due to type I error and to assess the statistical power of pooled data (Figure 6). While a conventional significance threshold ( $\mathrm{z}=1.96$; solid green line) was not reached by pooling the three earlier trials ${ }^{5-7}$, at cumulative analysis the addition of the CLOSE trial $^{12}$ produced a significant variation $(p=0.043)$ that would be spurious when accounting for type I error. After the addition of the Gore REDUCE trial ${ }^{13}$, the cumulative $\mathrm{z}$ curve $(\mathrm{z}=2.599)$ crossed the alpha spending function monitoring boundary $(z=2.075$; dashed red line). The relative weight of the Gore REDUCE trial ${ }^{13}$ on cumulative effect was greater than that of the CLOSE trial ${ }^{12}$ (Supplementary Figure 2) and, after switching the order of addition of the two trials, the cumulative $\mathrm{z}$ curve $(\mathrm{z}=2.284)$ crossed the monitoring boundary earlier $(\mathrm{z}=2.243)$.
At subgroup analysis (Figure 7), the stroke risk reduction after tPFOc seemed to be larger in patients $<45$ years old, males, with substantial shunt. However, no interaction between subgroups was observed.

TIA

The risk of TIA was not significantly reduced after tPFOc compared with ATA (HR 0.69, 95\% CI: 0.31-1.54, p=0.365) (Figure 8). The univariate sensitivity analysis using the number of events (ORs) was consistent (Supplementary Figure 3). No heterogeneity across trial-level estimates was observed $\left(\mathrm{I}^{2}=0 \%\right.$; $\left.\mathrm{p}=0.984\right)$.

\section{ATRIAL FIBRILLATION AND MAJOR BLEEDING}

Compared with ATA, tPFOc was associated with a more than fourfold increase in the risk of atrial fibrillation (Figure 9A). Heterogeneity was moderate $\left(\mathrm{I}^{2}=44.8 \% ; \mathrm{p}=0.124\right)$. The risk of major bleeding was overall low and comparable between treatments (Figure 9B). Heterogeneity was not significant $\left(\mathrm{I}^{2}=34.5 \%\right.$; $\mathrm{p}=0.191)$. Rates of other major cardiovascular adverse events are summarised in Supplementary Table 9.

\section{MIGRAINE}

Compared with ATA, tPFOc did not seem to produce any benefit in terms of migraine (Supplementary Figure 4).

\section{BIAS ASSESSMENT AND STUDY RELIABILITY}

Overall, the quality of the included trials was moderate-to-high, but some possible sources of bias need to be taken into account,

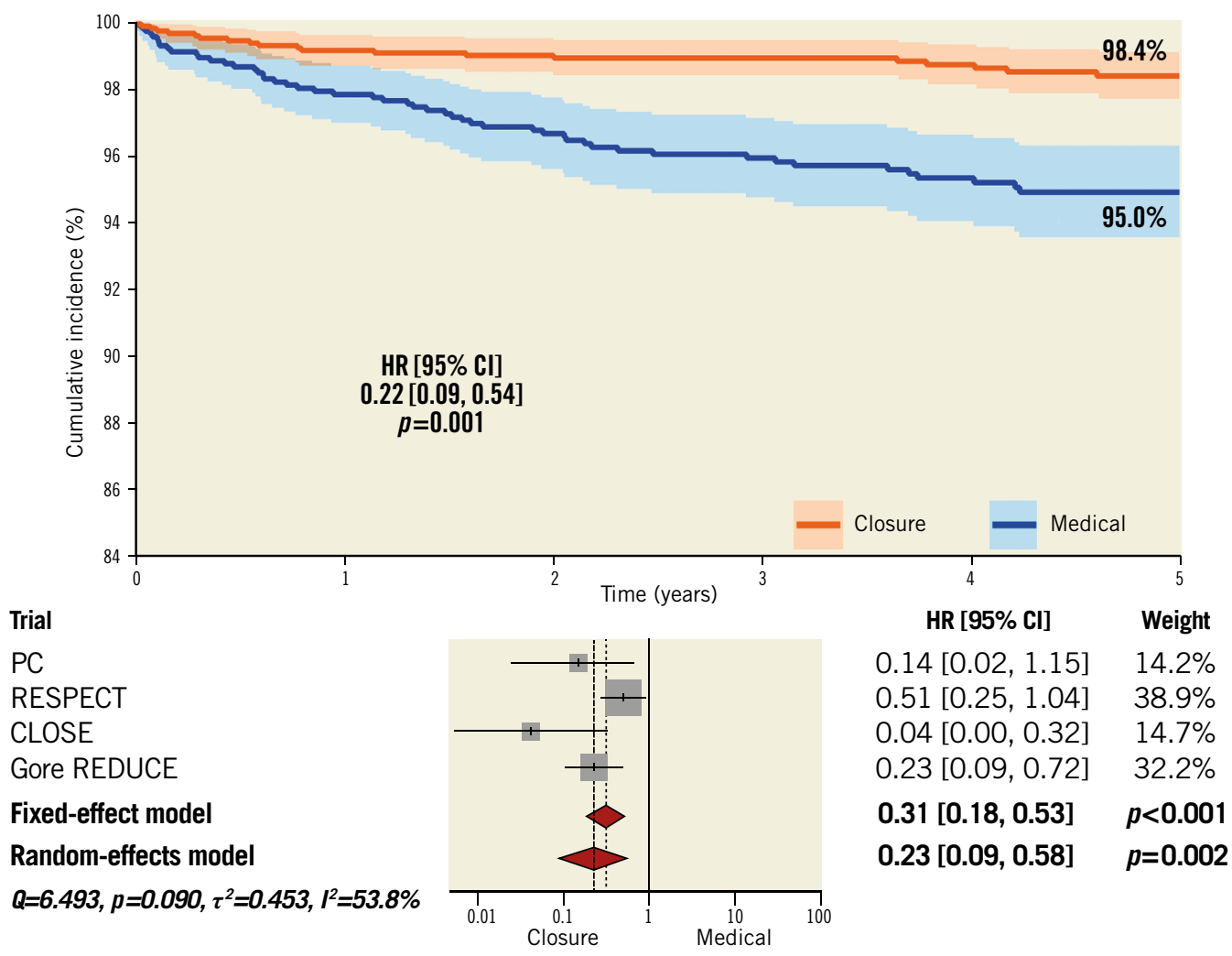

Figure 5. Five-year analysis after exclusion of trials with outdated devices and limited follow-up. 


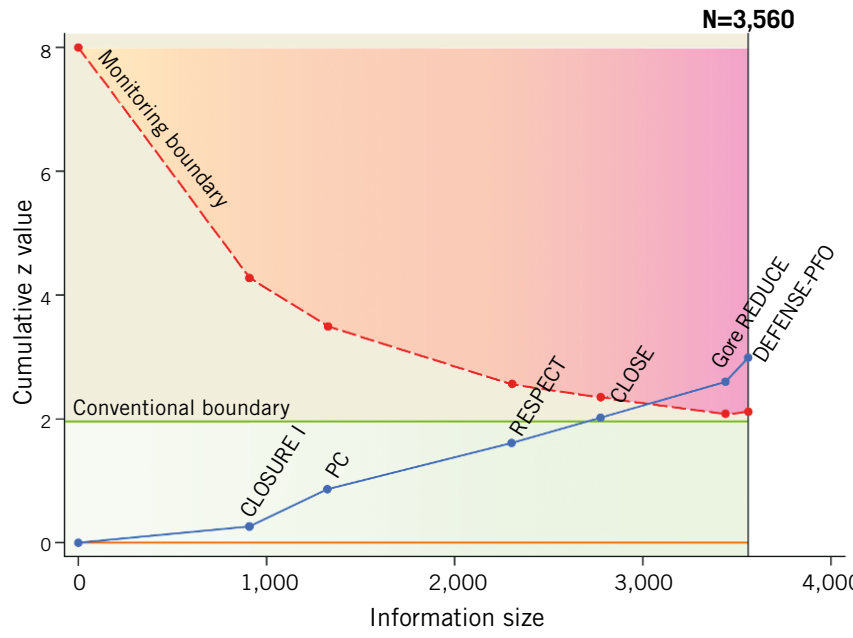

\begin{abstract}
Trial
Adding CLOSURE I

Adding PC

Adding RESPECT

Adding CLOSE

Adding Gore REDUCE

Adding DEFENSE-PFO

Random-effects model
\end{abstract}

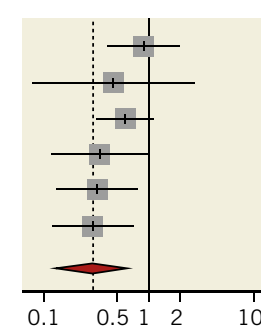

HR $[95 \% \mathrm{Cl}]$
$0.90[0.41,1.98]$
$0.46[0.08,2.66]$
$0.60[0.32,1.12]$
$0.34[0.12,0.97]$
$0.32[0.14,0.76]$
$0.28[0.12,0.64]$
$\mathbf{0 . 2 8}[0.12,0.64]$

Older trials

CLOSURE I

PC

RESPECT

Fixed-effect model

Random-effects model

$Q=2.919, p=0.232, \tau^{2}=0.100, I^{2}=31.5 \%$

Newer trials

CLOSE

Gore REDUCE

DEFENSE-PFO

Fixed-effect model

Random-effects model

$Q=2.213, p=0.201, \tau^{2}=0.504, I^{2}=37.7 \%$

Interaction fixed-effect: 0.003

Interaction random-effects: 0.018

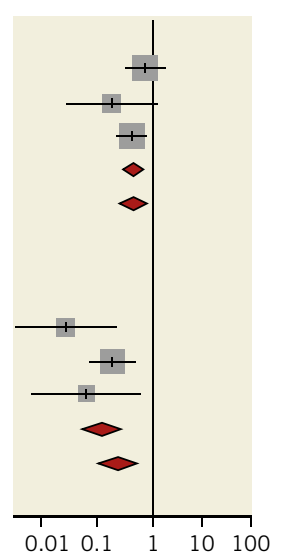

HR $[95 \% \mathrm{Cl}]$

$0.90[0.41,1.98]$

$0.14[0.02,1.15]$

$0.55[0.31,1.00]$

$0.61[0.39,0.97]$

$0.60[0.32,1.12]$

\section{p-value}

0.793

0.388

0.107

0.043

$0.009 \cdot 2.599$

$0.003 \quad 2.989$

$p=0.003$

$\mathbf{z}$
0.262

0.864

MB
4.289

3.500

2.559

2.344

2.075

2.102
$0.03[0.00,0.26] \quad 10.0 \%$

$0.23[0.09,0.62] \quad 21.1 \%$

$0.07[0.00,0.75] \quad 9.0 \%$

$0.15[0.06,0.34] \quad 40.0 \% \quad p<0.0001$

$0.11[0.03,0.39] \quad 40.0 \% \quad p<0.0001$ $p=0.038$

$p=0.107$

Figure 6. Trial sequential analysis, cumulative meta-analysis and comparison between earlier and newer trials. Red numbers indicate when the cumulative risk reaches statistical significance. MB: monitoring boundary

Age

$<45$ years

$\geq 45$ years

Gender

Male

Female

Shunt

Non-substantial

Substantial

\section{Closure}

8/1,659

20/2,106

$12 / 1,971$

$16 / 1,807$

$11 / 1,328$

$16 / 2,353$

\section{Medical}

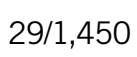

$34 / 1,861$

29/1,773

$34 / 1,524$

21/1,303

$32 / 1,914$ 


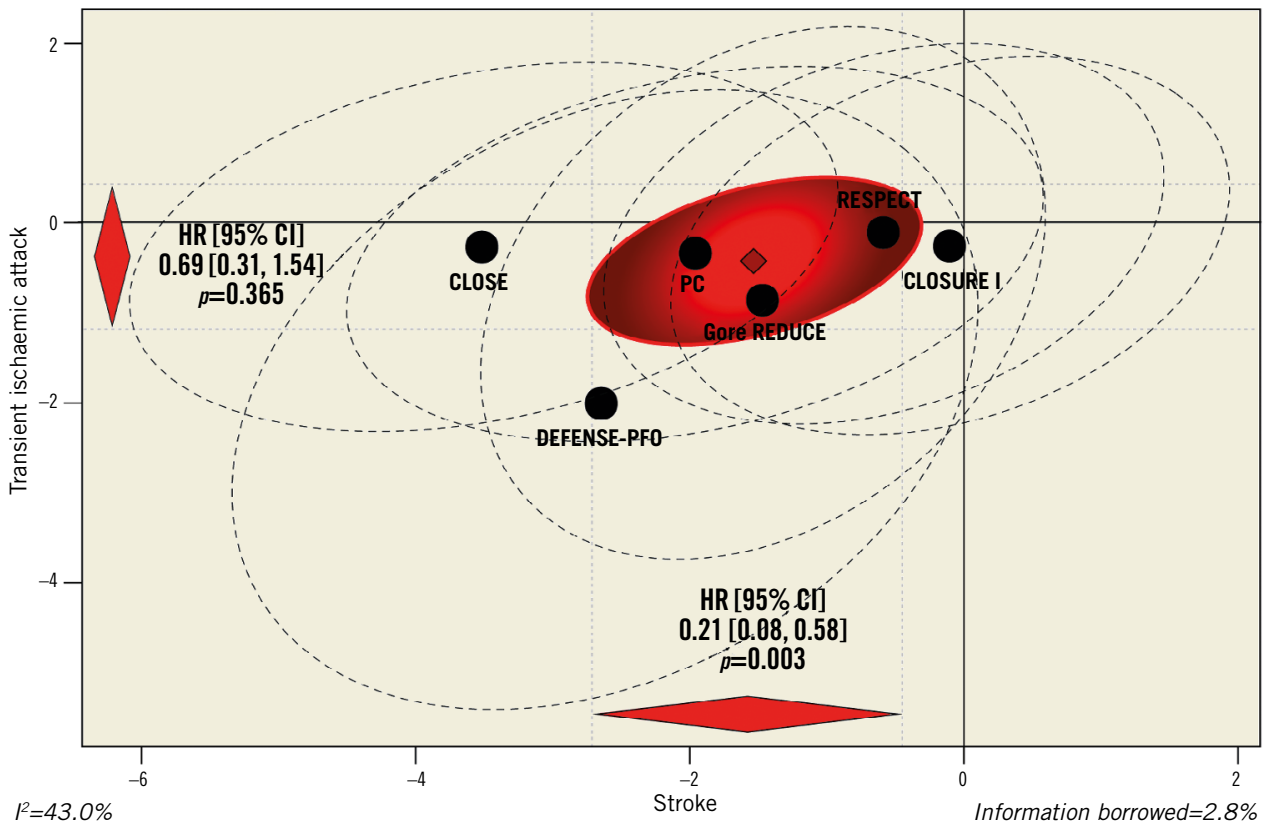

Figure 8. Multiple-outcome meta-analysis of stroke and TIA.

as illustrated in Supplementary Figure 5. According to GRADE ${ }^{31}$, the reliability of our conclusions is acceptable (Supplementary Table 10).

\section{Discussion}

The findings of this meta-analysis can be summarised as follows:

1) compared with ATA, tPFOc reduces the risk of stroke at very long-term follow-up; 2) the results are robust, do not depend on individual trials and do not change across analyses accounting for multiple testing and clinical subgroups; 3) although substantial heterogeneity was observed, this depended on differences in magnitude rather than direction of treatment effects; 4) although pathophysiologically correlated with stroke, tPFOc does not

$\begin{array}{lrc}\text { A } \text { Trial } & \text { Closure } & \text { Medical } \\ \text { CLOSURE I } & 24 / 447 & 3 / 462 \\ \text { PC } & 6 / 204 & 2 / 214 \\ \text { RESPECT } & 15 / 499 & 8 / 481 \\ \text { CLOSE } & 10 / 238 & 2 / 235 \\ \text { Gore REDUCE } & 29 / 441 & 1 / 223 \\ & \mathbf{8 4 / 1 , 8 2 9} & \mathbf{1 6 / 1 , 6 1 5}\end{array}$

Fixed-effect model Random-effects model $Q=7.133, p=0.129, \tau^{2}=0.367, I^{2}=43.9 \%$

$\begin{array}{lrc}\text { B } \text { Trial } & \text { Closure } & \text { Medical } \\ \text { CLOSURE I } & 10 / 447 & 4 / 462 \\ \text { PC } & 1 / 204 & 3 / 214 \\ \text { RESPECT } & 3 / 499 & 1 / 481 \\ \text { CLOSE } & 2 / 238 & 5 / 235 \\ \text { Gore REDUCE } & \mathbf{8 / 4 4 1} & \mathbf{6 / 2 2 3} \\ & \mathbf{2 4 / 1 , 8 2 9} & \mathbf{1 9 / 1 , 6 1 5}\end{array}$

Fixed-effect model Random-effects model $Q=6.105, p=0.191, \tau^{2}=0.318, I^{2}=34.5 \%$

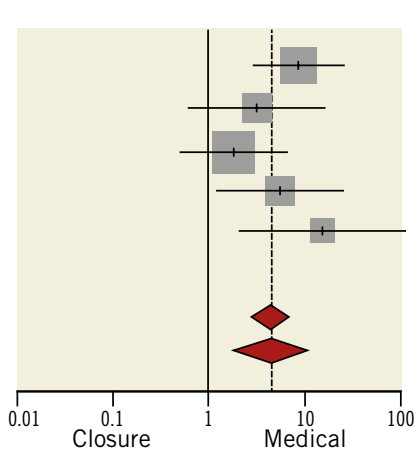

HR [95\% Cl] Weight

$8.68[2.60,29.04] \quad 23.1 \%$

$3.21[0.64,16.10] \quad 16.5 \%$

$1.83[0.77,4.36] \quad 30.6 \%$

$5.11[1.11,23.58] \quad 17.6 \%$

$15.63[2.11,115.48] 12.2 \%$

$4.70[2.72,8.12]$

$p<0.001$

$4.48[1.99,10.10] \quad p<0.001$

HR [95\% Cl]

Weight

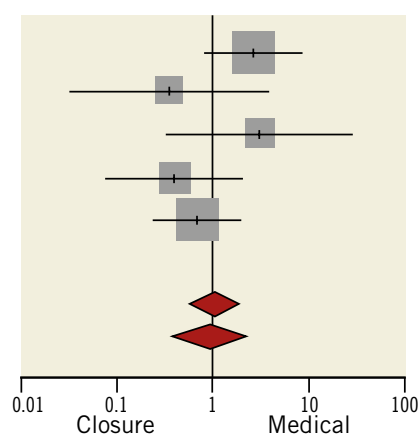

$2.62[0.82,8.42]$

$28.1 \%$

$0.35[0.04,3.36]$

$11.4 \%$

$2.90[0.30,28.01]$

$11.4 \%$

$0.39[0.07,2.03]$

$18.4 \%$

$0.67[0.23,1.95]$

$30.7 \%$

$1.03[0.56,1.89]$

$p=0.925$

$0.98[0.42,2.29]$

Figure 9. Atrial fibrillation and major bleeding. A) Atrial fibrillation. B) Major bleeding. 
protect from TIA; 5) tPFOc imposes a higher post-procedural risk of atrial fibrillation, while no difference in major bleeding was observed; 6) no benefit of tPFOc against migraine is observed.

A major finding of our study was that the relative risk reduction of stroke was detectable after approximately one year after enrolment and continued to accrue with increasing duration of surveillance. Considering that each trial has no power for stroke (i.e., design for composite endpoints, anticipated termination, lower than expected incidence of events), extended follow-up enables capturing a larger number of events. The non-significant results observed in the primary analyses of the PC and RESPECT trials ${ }^{6,7,32}$ should be interpreted against this background; over a shortto-medium time horizon, the incidence of stroke was insufficient to prove the benefit of tPFOc, as suggested by secondary analyses with extended follow-up ${ }^{4,32}$.

However, this finding can only partially explain the different results observed between earlier and newer trials. Indeed, several factors might have contributed to the strong conclusions of the recent CLOSE, Gore REDUCE, and DEFENSE-PFO trials ${ }^{12-14}$, despite sample size or follow-up time comparable with previous trials. First, the selection of patients in newer trials may have played a key role. In the CLOSURE I and PC trials ${ }^{5,6}$, a recent TIA or peripheral embolism could justify enrolment, while in the other trials ${ }^{7,12-14,32}$ almost exclusively patients who experienced cryptogenic stroke were considered for inclusion. Moreover, in earlier trials ${ }^{5-7}$, a relevant proportion of patients - about $50 \%$ in the CLOSURE I trial ${ }^{5}$ - had a small shunt, while in recent trials $^{12-14}$ patients with a substantial shunt were mostly enrolled. Second, in the CLOSE and in other recent trials ${ }^{12-14}$, the longer experience gained may have led to more effective procedures by proper anatomic assessment and device size selection. Third, differences in devices and medical therapy may have influenced the results of trials. The CLOSURE I trial ${ }^{5}$ employed the use of a double umbrella-like occluder comprised of a nickel-cobalt framework with attached polyester fabric that might not have worked as well as other devices ${ }^{5,33,34}$. Consistent with observational data, the three trials ${ }^{7,14,32}$ based on a double-disc occluder device comprising a self-expanding nitinol mesh with a sewn polyester patch showed not only improved results but also fewer complications. Similarly, the Gore REDUCE trial ${ }^{13}$, which tested double-disc occluders comprising a platinum-filled nitinol wire frame covered with expanded polytetrafluoroethylene, showed a strong reduction in the risk of stroke after tPFOc. However, in the CLOSE trial $^{12}$ - the investigation showing the most pronounced stroke risk reduction and the absence of stroke in the tPFOc group - several available devices were implanted in mixed proportions.

The impact of different ATA regimens in patients allocated to conservative treatment should also be considered. In the CLOSURE I, PC, and RESPECT trials ${ }^{5-7}$, as well as in observational studies ${ }^{35}$, outcomes were comparable between patients receiving anticoagulation and antiplatelet therapy. In the CLOSE trial ${ }^{12}$, the randomised comparison of anticoagulation versus antiplatelet therapy showed a numerical trend favouring anticoagulation. Conversely, in the
RESPECT trial ${ }^{7,32}$, there was a significant risk reduction associated with antiplatelet therapy, although interaction testing was borderline. No information was provided for the DEFENSE-PFO trial ${ }^{14}$.

We also performed landmark time-to-event analysis to provide estimates accounting for the overall significant loss of patients at follow-up and to assess consistency of results over time. Indeed, a significant proportion of patients were right-censored from two to five years, probably as a result of the limited per-protocol follow-up requirements of the CLOSURE I, Gore REDUCE and DEFENSE-PFO trials ${ }^{5,13,14}$ and originally unplanned very late follow-up in the RESPECT trial ${ }^{32}$. In addition, the proportion of patients who were lost at follow-up was higher in the ATA group ${ }^{4}$. The significant proportion of patients with incomplete followup represents an important limitation of trials and must be borne in mind when interpreting very late outcomes. Nevertheless, our analysis showed evidence that the curves continue to diverge after two years and the number of events in the ATA group increases over time.

Importantly, some authors might argue about the inclusion of the CLOSURE I trial ${ }^{5}$ because, after disclosure of the results, the tested device was labelled as ineffective. From a meta-analytic point of view, the exclusion of a trial from the main analysis based on the missing detection of differences between groups or the subjective experience of the investigator would imply a publication bias. However, we performed a sensitivity analysis with the aim of reducing factors potentially inflating the imprecision of pooled estimates. In this analysis, we excluded the CLOSURE I and DEFENSE-PFO trials ${ }^{5,14}$ - since conclusions about specific device performance might be fair and trials with significantly shorter follow-up lengths could influence results - and applied a five-year right-censoring time to reduce inference based on limited numbers at risk. Despite these restrictions, pooled estimates were quite consistent with those computed in the main analysis.

Importantly, tPFOc cannot abolish the risk of recurrent stroke in patients with PFO and, although a significant proportion of cerebrovascular events in the interventional group may be related to suboptimal closure, causal relationships with additional factors, such as microembolism or thrombus formation on the implanted device, cannot be completely excluded ${ }^{2,36}$. In support of that, we found that the risk of TIA was comparable between groups without signals of heterogeneity. The diagnosis of TIA can be challenging compared with stroke. However, in the included trials, the occurrence of TIA was based on clinical and brain imaging data, acute cerebrovascular events during follow-up needed to be assessed by the neurologist, and atypical or unclear symptoms were not considered if not supported by further evidence. The comparable risk of TIA between groups perhaps implies the persistence in some patients who underwent tPFOc of imperceptible shunting that is not able to produce stroke but maintains some predisposition to embolisation through the interatrial septum. In addition, some anatomic characteristics, such as interatrial septal aneurysm, may confound the correlation between the significant stroke risk reduction and the lack of benefit in terms of TIA. 
An important finding was that the development of atrial fibrillation is significantly higher in patients who undergo tPFOc compared with those receiving ATA. Nevertheless, the results of our analysis suggest that the net benefit of tPFOc is clear in spite of this. The review of data from the included trials shows that atrial fibrillation had onset generally limited to the early post-procedural time and in most cases was paroxysmal or treated successfully by electrical or pharmacologic cardioversion without recurrence over follow-up (59-100\%). In addition, only a very small proportion of strokes in the tPFOc group had a causal relationship with atrial fibrillation. However, although the available results have acceptable follow-up length, the impact of a permanent implant on the overall risk of stroke, propensity to develop persistent atrial fibrillation and need for anticoagulation after several decades remains unexplored ${ }^{37}$. Procedural safety is further confirmed by similar incidences of major bleeding between groups. The young and low-risk profile of the enrolled patients did not lead to an excess of events in the ATA group.

The review of other major adverse events after $\mathrm{tPFOc}$ did not raise concerns ${ }^{4-7,12-14,32}$, with the exception of a higher incidence of pulmonary embolism in the RESPECT trial ${ }^{7,32}$, which was probably not related to the device and could be explained by the persistence of the source of embolism after successful tPFOc. Procedure- and device-related serious adverse events were very low across trials, ranging from $3.9 \%$ to $7.9 \%$, and no differences in cumulative rates of any type of serious adverse event emerged between groups. Yet, heterogeneous reporting of information across trials was observed. Mortality over time was very low in both groups, and frequently events had a non-cardiac and non-neurologic cause.

Early observational reports suggested a possible secondary benefit of tPFOc in terms of reduction of the incidence of migraine ${ }^{38}$. However, a recent small trial has not shown a significant reduction in monthly migraine days ${ }^{38}$. Although it is mandatory to consider that in trials included in our meta-analysis the appropriate assessment of migraine was not among endpoints and the clinical subset did not necessarily comprise patients with a history of migraine, our meta-analysis indicates no benefit from $\mathrm{tPFOc}$.

In aggregate, our review highlights that tPFOc can significantly reduce the risk of stroke over time compared with ATA, but the benefit seems to depend significantly on proper selection of patients in terms of clinical history and high-risk PFO characteristics. Currently, procedures performed for TIA or migraine do not present acceptable evidence-based support.

\section{Limitations}

As with any meta-analysis, regardless of aggregate data or reconstructed time-to-event data, our results depend on original investigations and share the same limitations. We did not have access to the full data set. However, we reconstructed original data according to a validated methodology having a minimal - but unavoidable margin of imprecision ${ }^{25,26}$. The very large margin of significance/ non-significance of pooled estimates as well as the strong consistency observed across multiple rigorous analyses make our conclusions robust and reliable.

In addition, the following limitations should be considered. First, with respect to the endpoints of atrial fibrillation and major bleeding, the mixed reporting across trials imposed the use of ORs as outcome measure instead of HRs. In addition, in the Gore REDUCE trial ${ }^{13}$, events were provided as atrial fibrillation or atrial flutter. Yet, the number of atrial flutters was described as being extremely low. Second, in the report of the Gore REDUCE trial $^{13}$, the endpoint of TIA was not reported as an HR. We overcame this limitation by the "borrowing of strength" of multipleoutcome meta-analysis. In addition, we performed a sensitivity analysis by using counts (ORs) - reported for all the trials; results did not change. Third, in the CLOSURE I trial ${ }^{5}$, atrial fibrillation and major bleeding were shown according to per-protocol analysis. We handled denominators according to as-randomised values to be consistent with the other trials that presented results according to intention-to-treat analysis. Fourth, in the subgroup analyses of the CLOSE and Gore REDUCE trials ${ }^{12,13}$ ( $<44.6$ versus $\geq 44.6$ and $\leq 45$ versus $>45$, respectively), the age cut-off differed trivially from the one we used ( $<45$ versus $\geq 45$ ), but the impact is considered insignificant. Moreover, with respect to subgroup analyses, in the CLOSE trial ${ }^{12}$ data were shown as any shunt plus atrial septal aneurysm, thus were not considered in our study, while in the DEFENSE-PFO trial ${ }^{14}$ no result was presented according to major clinical subgroups, thus data could not be pooled. Finally, in the DEFENSE-PFO trial ${ }^{14}$, atrial fibrillation, major bleeding, and migraine were not shown.

\section{Conclusions}

Compared with ATA, tPFOc significantly reduces the risk of stroke at long-term follow-up. However, no difference was observed in terms of TIA. The risk of atrial fibrillation is higher after tPFOc but generally early and transient. Major bleeding and migraine are comparable with ATA.

\section{Impact on daily practice}

Currently, the European Stroke Organisation indicates tPFOc only in patients with cryptogenic stroke and PFO with highrisk features, while the American Heart Association/American Stroke Association guidelines consider tPFOc a viable alternative to ATA only in patients with PFO and recurrent deep vein thrombosis. This meta-analysis shows that accumulated evidence from randomised clinical trials is robust enough to prove a significant stroke risk reduction after tPFOc compared with ATA in patients with history of cryptogenic stroke confirmed by brain imaging. The safety profile of tPFOc is good overall but associated with a higher risk of atrial fibrillation, though mostly paroxysmal or successfully cardiovertible and with onset limited to the first period. No advantage of tPFOc in terms of TIA and migraine was observed. 


\section{Guest Editor}

This paper was guest edited by Alec Vahanian, $\mathrm{MD}, \mathrm{PhD}$; Department of Cardiology, Hôpital Bichat-Claude Bernard, and University Paris VII, Paris, France.

\section{Conflict of interest statement}

All the authors declare no support from any organisation for the submitted work, no financial relationships with any organisations that might have an interest in the submitted work in the previous three years, and no other relationships or activities that could appear to have influenced the submitted work. D. Giacoppo has received grants from the European Association of Percutaneous Cardiovascular Interventions (EAPCI). R. Byrne has received lecture fees from B. Braun Melsungen AG, Biotronik and Boston Scientific, and institutional research grants from Boston Scientific and HeartFlow. The other authors have no conflicts of interest to declare. The Guest Editor is a consultant for Edwards Lifesciences.

\section{References}

The complete list of references can be found in the online version of this paper.

\section{Supplementary data}

Supplementary Appendix 1. List of included trials.

Supplementary Appendix 2. Supplementary methods.

Supplementary Figure 1. Flow diagram.
Supplementary Figure 2. Trial sequential analysis after switching the order of addition of two simultaneously disclosed trials, Gore REDUCE and CLOSE.

Supplementary Figure 3. Sensitivity analysis of TIA.

Supplementary Figure 4. Risk of migraine.

Supplementary Figure 5. Bias assessment across the included trials. Supplementary Table 1. PRISMA checklist.

Supplementary Table 2. Literature search.

Supplementary Table 3. Key eligibility criteria across the included trials. Supplementary Table 4. Main clinical and anatomic characteristics by group.

Supplementary Table 5. Main clinical and anatomic characteristics by trial.

Supplementary Table 6. Antiplatelet and anticoagulant medications in patients assigned to PFOc and ATA across the included trials. Supplementary Table 7. Primary endpoints and definitions of stroke across the included trials.

Supplementary Table 8. Ischaemic stroke across trials and followup time points.

Supplementary Table 9. Main adverse cardiovascular events other than atrial fibrillation and major bleeding across the included trials. Supplementary Table 10. Evaluation according to GRADE of the overall reliability of the conclusions provided.

The supplementary data are published online at: http://www.pcronline.com/ eurointervention/141st issue/154 


\section{Supplementary data}

\section{Supplementary Appendix 1. List of included trials.}

\section{- CLOSURE I I,5,39,40}

Evaluation of the STARFlex Septal Closure System in Patients with a Stroke and/or Transient Ischemic Attack due to Presumed Paradoxical Embolism through a Patent Foramen Ovale.

\section{- $\mathrm{PC}^{6,41}$}

Clinical Trial Comparing Percutaneous Closure of Patent Foramen Ovale Using the Amplatzer PFO Occluder with Medical Treatment in Patients with Cryptogenic Embolism.

\section{- RESPECT ${ }^{4,7,32}$}

Randomized Evaluation of Recurrent Stroke Comparing PFO Closure to Established Current Standard of Care Treatment.

\section{- CLOSE ${ }^{12}$}

Patent Foramen Ovale Closure or Anticoagulants versus Antiplatelet Therapy to Prevent Stroke Recurrence.

\section{- Gore REDUCE ${ }^{13}$}

GORE ${ }^{\circledR}$ HELEX ${ }^{\circledR}$ Septal Occluder / GORE ${ }^{\circledR}$ CARDIOFORM Septal Occluder for Patent Foramen Ovale Closure in Stroke Patients.

\section{- DEFENSE-PFO ${ }^{14}$}

Device Closure Versus Medical Therapy for Cryptogenic Stroke Patients with High-Risk Patent Foramen Ovale. 


\section{Supplementary Appendix 2. Supplementary methods.}

\section{Reconstruction of time-to-event data and risk estimation}

High-quality Kaplan-Meier graphs were downloaded for each trial. Each curve was digitised at extreme magnification in order to retrieve spatial information. Data on the $\mathrm{x}$ and $\mathrm{y}$ axes were modelled along with number of events, numbers at risk, and thus number of right-censoring for each time interval (year) to estimate the survival function. The process was individually applied to each curve (treatment group) and performed for each trial. Reconstructed time-to-event analyses were used to draw the cumulative incidence of events over time ${ }^{42}$. Reconstructed data for the CLOSURE I trial ${ }^{5}$ derived from a Kaplan-Meier curve describing the composite endpoint of stroke or transient ischaemic attack (TIA). We obtained data related to stroke by subtracting from the reconstructed time-to-event data of the pooled analysis by Kent and colleagues ${ }^{4}$ the components of the PC and RESPECT trials ${ }^{6,7,32}$. With respect to the DEFENSE-PFO trial ${ }^{14}$, a Kaplan-Meier curve was available only for the primary composite endpoint ( 6 events) but, given a difference of a single event compared with ischaemic stroke ( 5 events), we identified the outcome of interest guided by the agreement between computed and reported log-rank test p-values after sequential removal of each event at a time.

\section{Supplementary specifications on statistical analysis}

According to a "one-stage" meta-analysis, the risk of stroke between groups was obtained directly by mixed-effects Cox hazards regression accounting for the original clustering of patients across trials ${ }^{27}$. As generally recommended, Cox proportional hazards regressions were carried out 
for each trial to obtain trial-level risk estimates which were subsequently pooled by random-effects models ("two-stage" meta-analysis). Proportional assumption was graphically inspected by the "log minus log" plot and tested according to the Schoenfeld residuals ${ }^{43}$. Given the absence of events in the tPFOc group of the CLOSE and DEFENSE-PFO trials ${ }^{12,14}$, the estimation of the risk of stroke between treatments was performed by Firth's penalised maximum likelihood bias reduction method for Cox regression ${ }^{44}$. In the DEFENSE-PFO trial ${ }^{14}$, similar methodology was applied for the outcome of TIA.

In the Gore REDUCE trial ${ }^{13}$, the hazard ratio (HR) and $95 \%$ confidence interval (CI) for TIA was not reported and only counts in the two groups were available. This limitation was overcome by the borrowing of information of multiple-outcome meta-analysis. According to univariate analyses, a low correlation (0.3) between stroke and TIA was primarily assumed. In the DEFENSE-PFO trial ${ }^{14}$, HR and $95 \% \mathrm{CI}$ for TIA were indirectly estimated as described elsewhere ${ }^{45}$.

Zero cells in fixed-effect and random-effects aggregate data meta-analyses were managed by "continuity correction" as recommended elsewhere ${ }^{46}$.

\section{Bias assessment}

Trial-level qualitative assessment was performed by using the Cochrane Collaboration tool ${ }^{21}$. Seven domains were individually assessed: sequence generation, allocation concealment, blinding of participants and personnel, blinding of outcome assessment, completeness of outcome data, 
selective reporting of outcome, and other potential sources of bias such as, for example, remarkable conflict of interests or selective financial support from industries or anticipated study termination. The risk of bias was graded as "low", "unclear", or "high" according to the individual review of the included trials ${ }^{21}$. The robustness of the conclusions of the meta-analysis was inspected according to the Grading of

Recommendations Assessment, Development and Evaluation (GRADE) ${ }^{31}$. The degree of confidence was graded as "very low", "low", "moderate" or "high"22. 


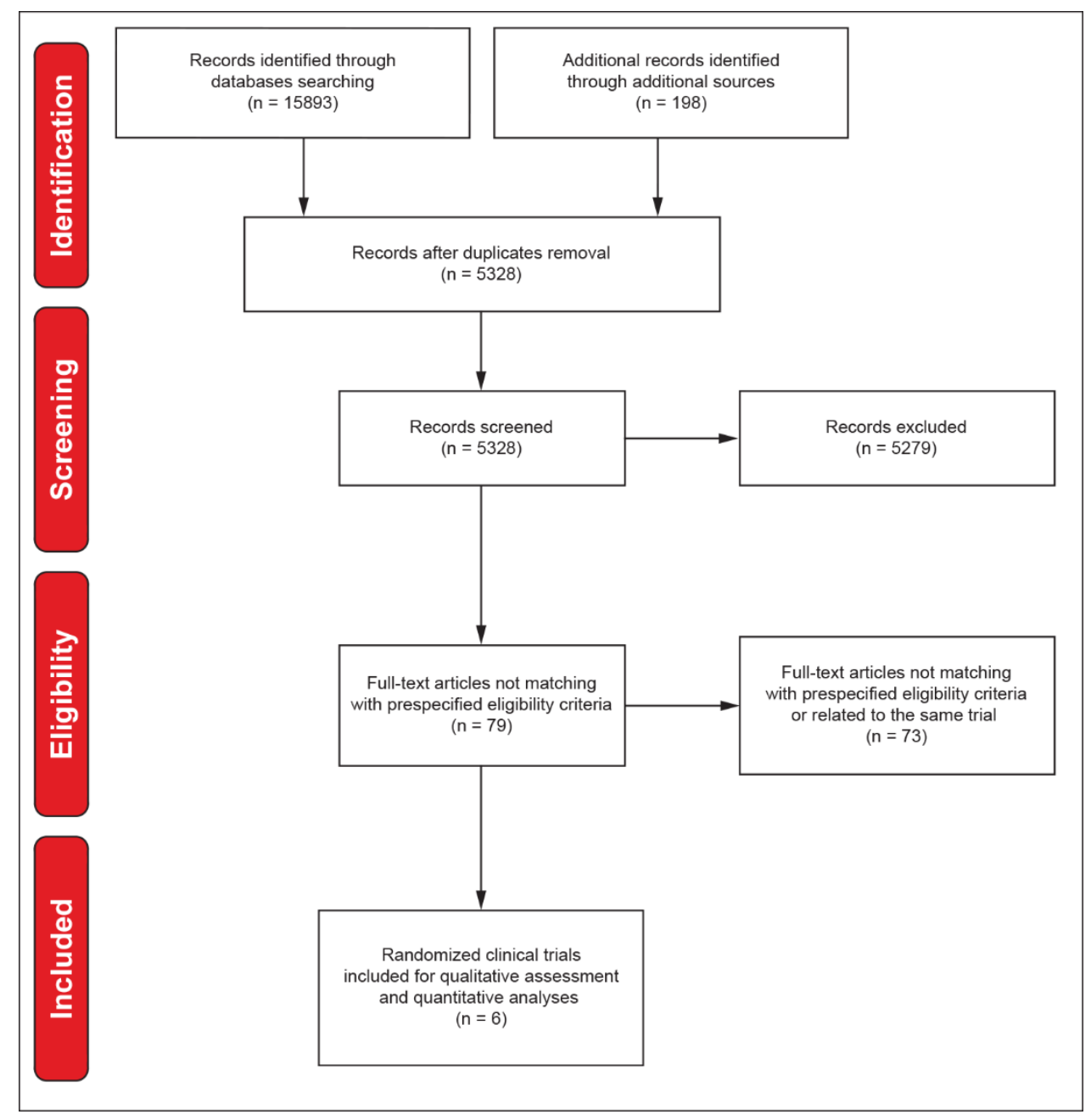

Supplementary Figure 1. Flow diagram.

In aggregate, a total of 15,893 reports were retrieved by multiple-database search, while 198 reports were identified by tangential exploration. After removal of duplicates, 5,328 reports underwent title- and abstract-level screening with exclusion of 5,279 of them because they did not match pre-specified eligibility criteria. Divergences among investigators were solved by consensus (N.C., A.H.F., J.M., D.G.). The other 79 reports 
underwent full-text screening and, when related to the same trial (i.e., study protocol, secondary analysis, pooled analysis, etc.) were appended to the main investigation and considered as part of a single unit. 


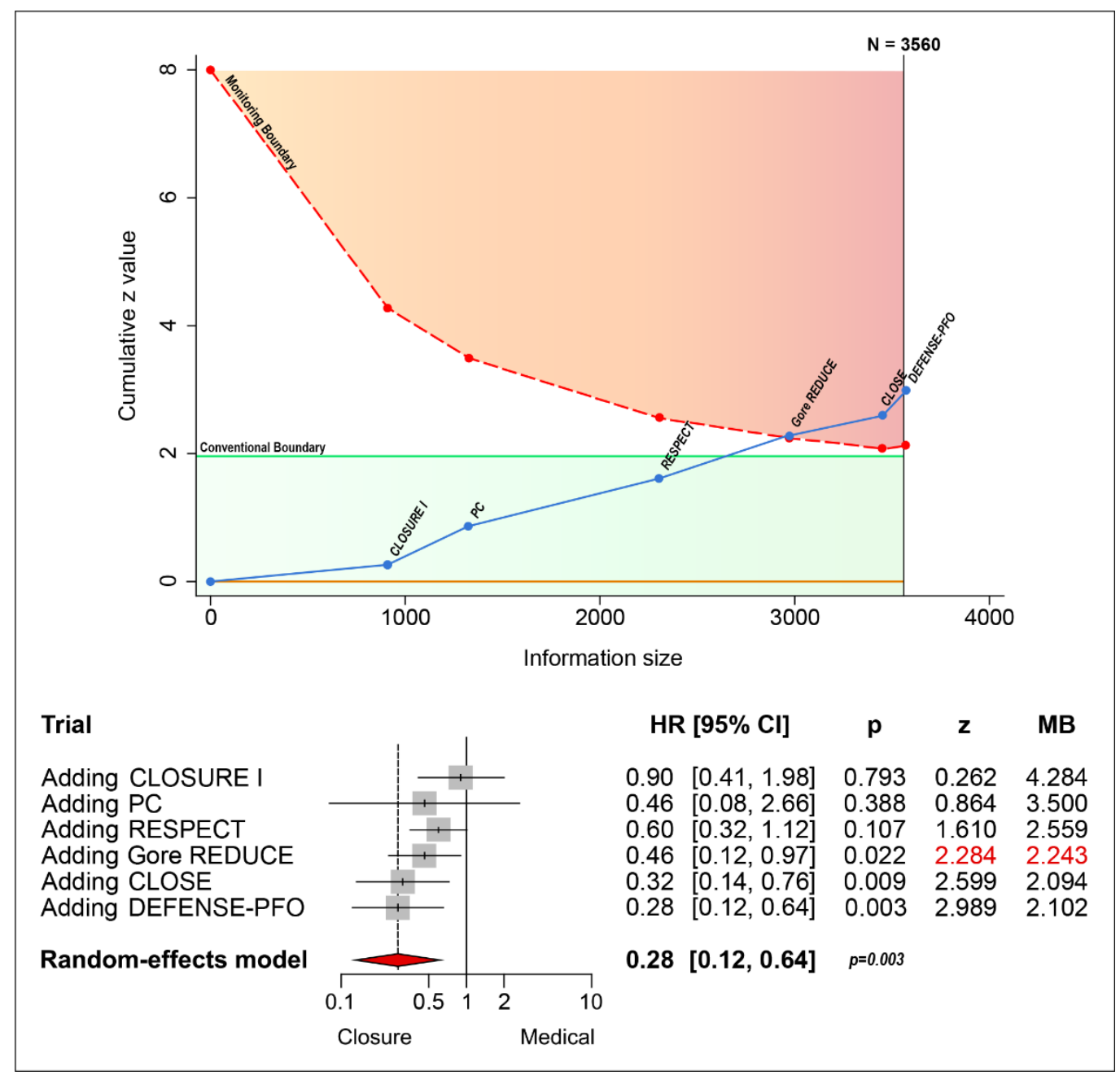

Supplementary Figure 2. Trial sequential analysis after switching the order of addition of two simultaneously disclosed trials, Gore REDUCE and CLOSE. 


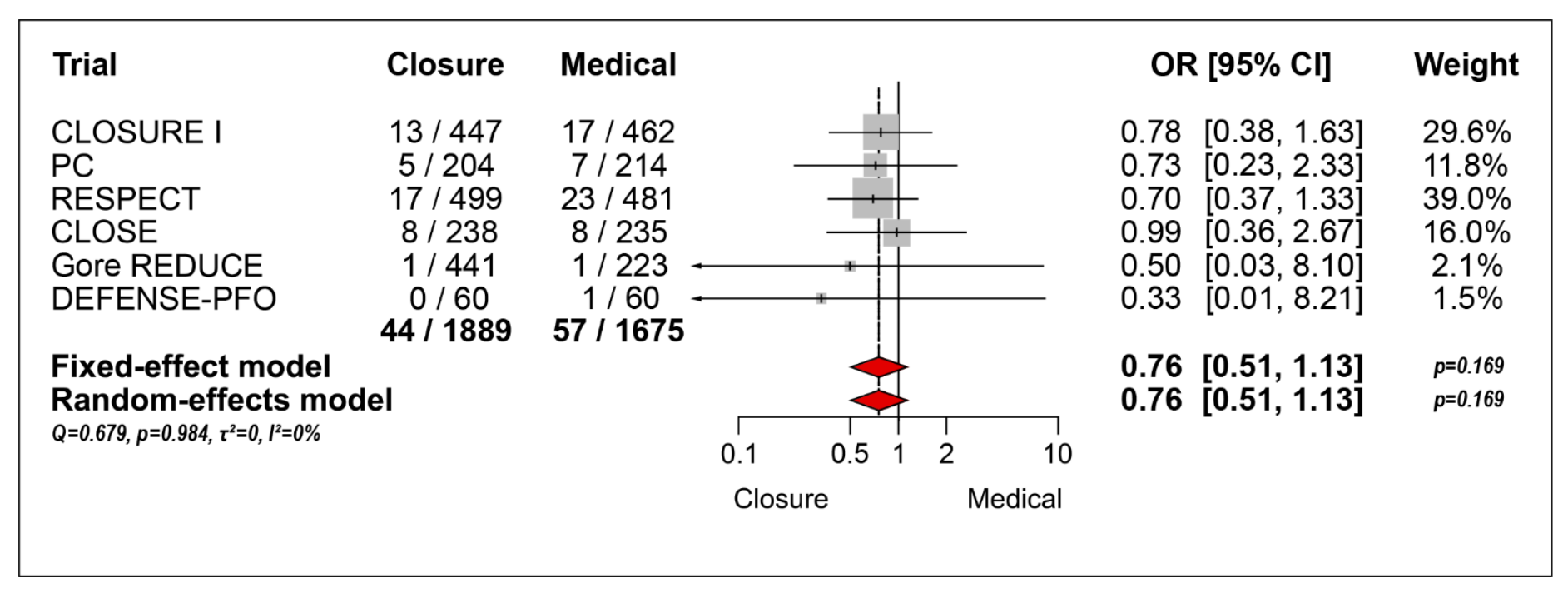

Supplementary Figure 3. Sensitivity analysis of TIA. 


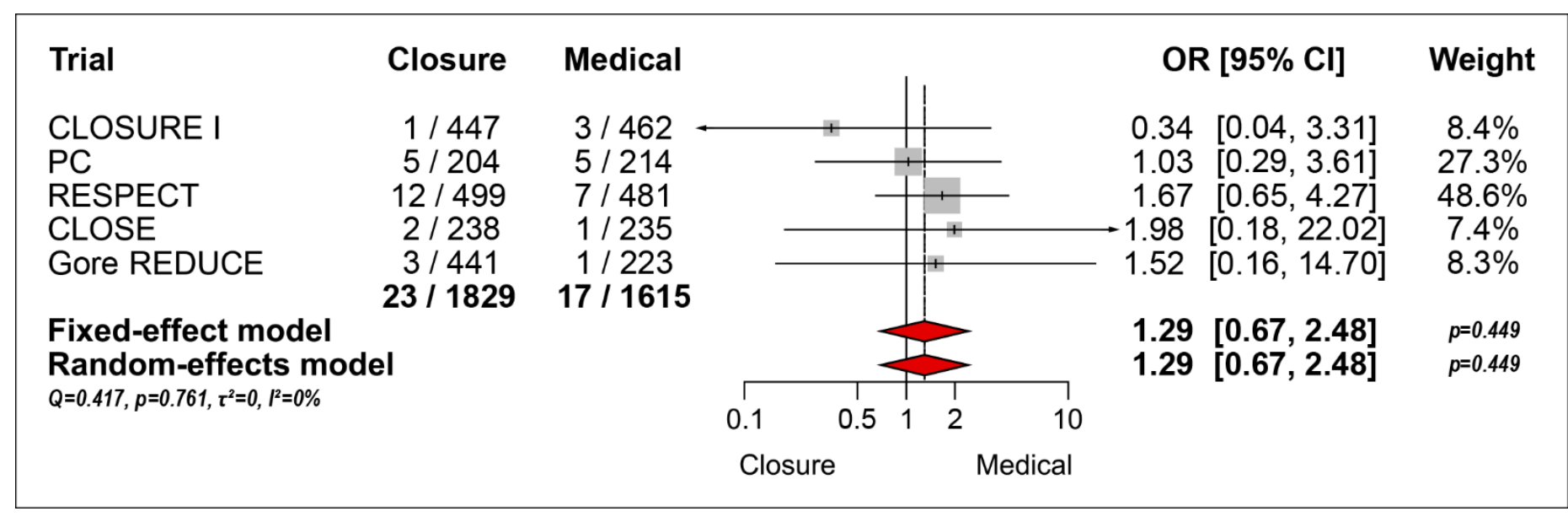

Supplementary Figure 4. Risk of migraine. 


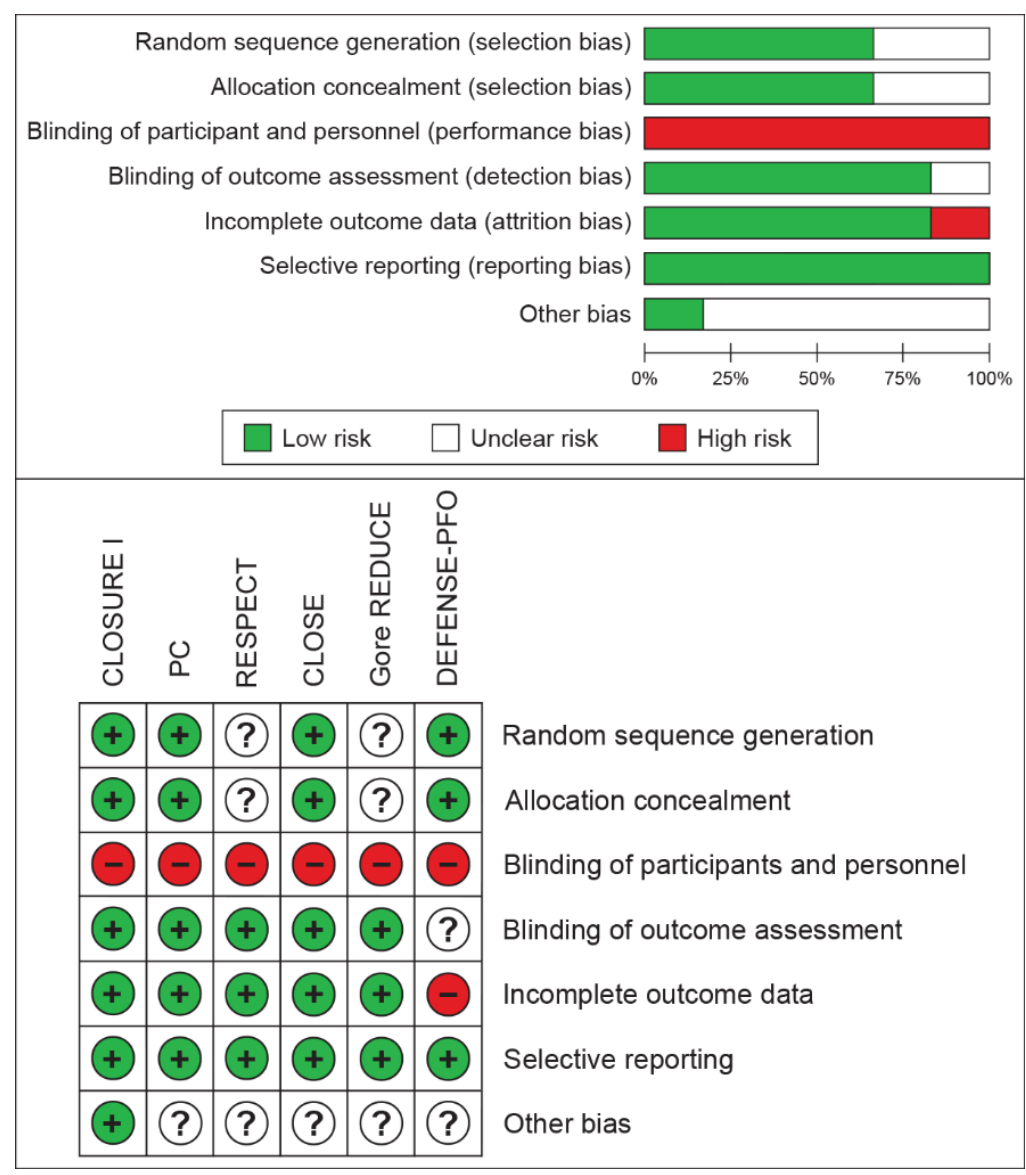

Supplementary Figure 5. Bias assessment across the included trials.

Given the dissimilar strategies under investigation, all the trials were open-label. In the RESPECT and Gore REDUCE trials ${ }^{7,13}$, the description of random sequence generation and allocation concealment was limited. Although these two methodologic aspects were likely performed as in the other trials, it was not possible to assess them due to missing information. Four trials ${ }^{5-7,13}$ received significant support from the manufacturer of the device implanted for $\mathrm{PFOc}$, sometimes contributing to the design, other times providing the statistical analyses, thus implying a minimum risk 
of bias. In the CLOSURE I trial ${ }^{5}$, however, even though only the STARFlex occluder was implanted, the impact of the sponsor might be considered less influential after review of the results. In the same trial, the original sample size $(n=1,600)$ was reduced to 800 patients (March 2007$)$ due to slow enrolment and later (June 2007) increased to 900 patients to obtain the minimum number of subjects evaluable ( $n=752$ ). The CLOSURE I, PC, RESPECT, Gore REDUCE and DEFENSE-PFO trials ${ }^{5-7,13,14}$ were powered for composite endpoints and observed incidences of stroke were lower than expected. In the Gore REDUCE trial ${ }^{13}$, the original primary endpoint of stroke was modified at interim analysis to a composite of stroke or brain imaging lesion. The CLOSE trial ${ }^{12}$ was investigator-initiated and supported by a government institution, but data were presented as a $2 \times 2$ design though the randomisation ratio was 1:1:1. In this trial ${ }^{12}$, the original sample size $(n=900)$ was not reached due to insufficient budget and investigation was terminated early. The DEFENSE-PFO trial ${ }^{14}$ was investigator-initiated and supported by a scientific research foundation, but terminated early and characterised by lower than expected incidences of events. In the same trial, blinding of outcome assessment is unclear, while some important secondary safety outcomes, such as atrial fibrillation or major bleeding, are not considered. 


\section{Supplementary Table 1. PRISMA checklist.}

\begin{tabular}{|c|c|c|c|}
\hline Section/topic & $\#$ & Checklist item & $\begin{array}{l}\text { Reported } \\
\text { on page \# }\end{array}$ \\
\hline \multicolumn{4}{|c|}{ TITLE } \\
\hline Title & 1 & Identify the report as a systematic review, meta-analysis, or both. & 1 \\
\hline \multicolumn{4}{|c|}{ ABSTRACT } \\
\hline $\begin{array}{l}\text { Structured } \\
\text { summary }\end{array}$ & 2 & $\begin{array}{l}\text { Provide a structured summary including, as applicable: background; objectives; data sources; study eligibility criteria, participants, and } \\
\text { interventions; study appraisal and synthesis methods; results; limitations; conclusions and implications of key findings; systematic review } \\
\text { registration number. }\end{array}$ & 2 \\
\hline \multicolumn{4}{|c|}{ INTRODUCTION } \\
\hline Rationale & 3 & Describe the rationale for the review in the context of what is already known. & 5 \\
\hline Objectives & 4 & $\begin{array}{l}\text { Provide an explicit statement of questions being addressed with reference to participants, interventions, comparisons, outcomes, and study } \\
\text { design (PICOS). }\end{array}$ & $\begin{array}{l}\text { 6-7, } \\
\text { Supplementary } \\
\text { Appendix }\end{array}$ \\
\hline \multicolumn{4}{|c|}{ METHODS } \\
\hline $\begin{array}{l}\text { Protocol and } \\
\text { registration }\end{array}$ & 5 & $\begin{array}{l}\text { Indicate if a review protocol exists, if and where it can be accessed (e.g., Web address), and, if available, provide registration information } \\
\text { including registration number. }\end{array}$ & 6 \\
\hline Eligibility criteria & 6 & $\begin{array}{l}\text { Specify study characteristics (e.g., PICOS, length of follow-up) and report characteristics (e.g., years considered, language, publication } \\
\text { status) used as criteria for eligibility, giving rationale. }\end{array}$ & $\begin{array}{l}\text { 6, } \\
\text { Supplementary } \\
\text { Appendix }\end{array}$ \\
\hline $\begin{array}{l}\text { Information } \\
\text { sources }\end{array}$ & 7 & $\begin{array}{l}\text { Describe all information sources (e.g., databases with dates of coverage, contact with study authors to identify additional studies) in the } \\
\text { search and date last searched. }\end{array}$ & $\begin{array}{l}\text { 6, } \\
\text { Supplementary } \\
\text { Appendix }\end{array}$ \\
\hline Search & 8 & Present full electronic search strategy for at least one database, including any limits used, such that it could be repeated. & $\begin{array}{l}\text { Supplementary } \\
\text { Appendix }\end{array}$ \\
\hline Study selection & 9 & $\begin{array}{l}\text { State the process for selecting studies (i.e., screening, eligibility, included in systematic review, and, if applicable, included in the meta- } \\
\text { analysis). }\end{array}$ & $\begin{array}{l}\text { 6, } \\
\text { Flow Diagram, } \\
\text { Supplementary } \\
\text { Appendix }\end{array}$ \\
\hline $\begin{array}{l}\text { Data collection } \\
\text { process }\end{array}$ & 10 & $\begin{array}{l}\text { Describe method of data extraction from reports (e.g., piloted forms, independently, in duplicate) and any processes for obtaining and } \\
\text { confirming data from investigators. }\end{array}$ & $\begin{array}{l}\text { 6, } \\
\text { Supplementary }\end{array}$ \\
\hline
\end{tabular}




\begin{tabular}{|c|c|c|c|}
\hline & & & Appendix \\
\hline Data items & 11 & List and define all variables for which data were sought (e.g., PICOS, funding sources) and any assumptions and simplifications made. & $\begin{array}{l}6, \\
\text { Supplementary } \\
\text { Appendix }\end{array}$ \\
\hline $\begin{array}{l}\text { Risk of bias in } \\
\text { individual } \\
\text { studies }\end{array}$ & 12 & $\begin{array}{l}\text { Describe methods used for assessing risk of bias of individual studies (including specification of whether this was done at the study or } \\
\text { outcome level), and how this information is to be used in any data synthesis. }\end{array}$ & $\begin{array}{l}10, \\
\text { Supplementary } \\
\text { Appendix }\end{array}$ \\
\hline $\begin{array}{l}\text { Summary } \\
\text { measures }\end{array}$ & 13 & State the principal summary measures (e.g., risk ratio, difference in means). & $7-9$ \\
\hline $\begin{array}{l}\text { Synthesis of } \\
\text { results }\end{array}$ & 14 & $\begin{array}{l}\text { Describe the methods of handling data and combining results of studies, if done, including measures of consistency (e.g., }{ }^{2} \text { ) for each meta- } \\
\text { analysis. }\end{array}$ & $7-8$ \\
\hline $\begin{array}{l}\text { Risk of bias } \\
\text { across studies }\end{array}$ & 15 & Specify any assessment of risk of bias that may affect the cumulative evidence (e.g., publication bias, selective reporting within studies). & $\begin{array}{l}7-9 \\
\text { Supplementary } \\
\text { Appendix }\end{array}$ \\
\hline $\begin{array}{l}\text { Additional } \\
\text { analyses }\end{array}$ & 16 & $\begin{array}{l}\text { Describe methods of additional analyses (e.g., sensitivity or subgroup analyses, meta-regression), if done, indicating which were pre- } \\
\text { specified. }\end{array}$ & $\begin{array}{l}8-9 \\
\text { Supplementary } \\
\text { Appendix }\end{array}$ \\
\hline \multicolumn{4}{|c|}{ RESULTS } \\
\hline Study selection & 17 & $\begin{array}{l}\text { Give numbers of studies screened, assessed for eligibility, and included in the review, with reasons for exclusions at each stage, ideally } \\
\text { with a flow diagram. }\end{array}$ & $\begin{array}{l}\text { 10, } \\
\text { Flow Diagram, } \\
\quad \text { Table 1, } \\
\text { Tables S3-S7, } \\
\text { Supplementary } \\
\quad \text { Appendix } \\
\end{array}$ \\
\hline $\begin{array}{l}\text { Study } \\
\text { characteristics }\end{array}$ & 18 & For each study, present characteristics for which data were extracted (e.g., study size, PICOS, follow-up period) and provide the citations. & $\begin{array}{l}\text { 10, } \\
\text { Flow Diagram, } \\
\text { Table 1, } \\
\text { Tables S3-S8, } \\
\text { Supplementary } \\
\text { Appendix }\end{array}$ \\
\hline $\begin{array}{l}\text { Risk of bias } \\
\text { within studies }\end{array}$ & 19 & Present data on risk of bias of each study and, if available, any outcome level assessment (see item 12). & $\begin{array}{c}13, \\
\text { Figure } 55, \\
\text { Table } \mathrm{S} 10\end{array}$ \\
\hline
\end{tabular}




\begin{tabular}{|c|c|c|c|}
\hline & & & $\begin{array}{c}\text { Supplementary } \\
\text { Appendix }\end{array}$ \\
\hline $\begin{array}{l}\text { Results of } \\
\text { individual } \\
\text { studies }\end{array}$ & 20 & $\begin{array}{l}\text { For all outcomes considered (benefits or harms), present, for each study: (a) simple summary data for each intervention group (b) effect } \\
\text { estimates and confidence intervals, ideally with a forest plot. }\end{array}$ & $\begin{array}{l}\text { 10-13, } \\
\text { Figures } 1 \\
\text { Supplementary } \\
\text { Appendix }\end{array}$ \\
\hline $\begin{array}{l}\text { Synthesis of } \\
\text { results }\end{array}$ & 21 & Present results of each meta-analysis done, including confidence intervals and measures of consistency. & $\begin{array}{c}10-13 \\
\text { Figures } 1-9, \\
\text { Supplementary } \\
\text { Appendix }\end{array}$ \\
\hline $\begin{array}{l}\text { Risk of bias } \\
\text { across studies }\end{array}$ & 22 & Present results of any assessment of risk of bias across studies (see Item 15). & $\begin{array}{l}13, \\
\text { Supplementary } \\
\text { Appendix }\end{array}$ \\
\hline $\begin{array}{l}\text { Additional } \\
\text { analysis }\end{array}$ & 23 & Give results of additional analyses, if done (e.g., sensitivity or subgroup analyses, meta-regression [see Item 16]). & \begin{tabular}{|c}
$10-13$, \\
Figures $2-7$, \\
Figure $\mathrm{S} 2$, \\
Figure $\mathrm{S} 3$ \\
Supplementary \\
Appendix
\end{tabular} \\
\hline \multicolumn{4}{|c|}{ DISCUSSION } \\
\hline $\begin{array}{l}\text { Summary of } \\
\text { evidence }\end{array}$ & 24 & $\begin{array}{l}\text { Summarize the main findings including the strength of evidence for each main outcome; consider their relevance to key groups (e.g., } \\
\text { healthcare providers, users, and policy makers). }\end{array}$ & $13-17$ \\
\hline Limitations & 25 & $\begin{array}{l}\text { Discuss limitations at study and outcome level (e.g., risk of bias), and at review-level (e.g., incomplete retrieval of identified research, } \\
\text { reporting bias). }\end{array}$ & $13-18$ \\
\hline Conclusions & 26 & Provide a general interpretation of the results in the context of other evidence, and implications for future research. & $13-19$ \\
\hline \multicolumn{4}{|c|}{ FUNDING } \\
\hline Funding & 27 & Describe sources of funding for the systematic review and other support (e.g., supply of data); role of funders for the systematic review. & $\begin{array}{l}\text { Supplementary } \\
\text { Appendix }\end{array}$ \\
\hline
\end{tabular}




\section{Supplementary Table 2. Literature search.}

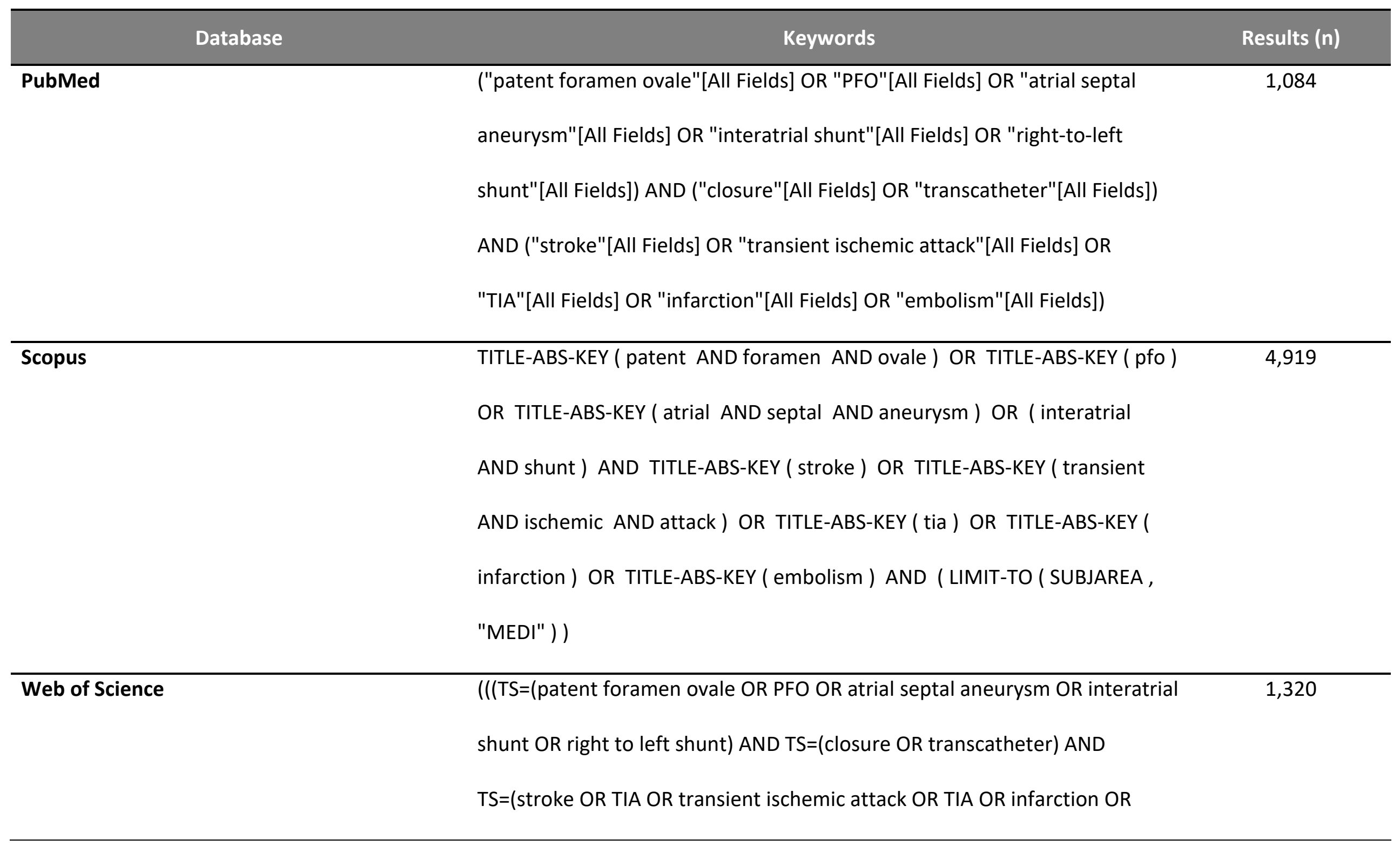


embolism)))) AND DOCUMENT TYPES: (Article OR Abstract of Published Item

OR Bibliography OR Book OR Book Chapter OR Database Review OR Letter

OR Meeting Abstract OR Proceedings Paper OR Review)

shunt" AND closure OR transcatheter AND stroke OR "transient ischemic

attack" OR TIA OR infarction OR embolism

All Sources(Medicine and Dentistry)

Ovid

(patent foramen ovale or PFO or atrial septal aneurysm or interatrial

4,652 shunt).af.

and

(closure or transcatheter).af.

and

(stroke or transient ischemic attack or TIA or infarction or embolism).af. 
Supplementary Table 3. Key eligibility criteria across the included trials.

\begin{tabular}{|c|c|c|}
\hline Trial & Inclusion criteria & Exclusion criteria \\
\hline CLOSURE I & $\begin{array}{l}\text { - Age } 18-60 \text { years old } \\
\text { - Positive bubble test by TEE demonstrating right-to-left } \\
\text { shunting through PFO during Valsalva manoeuvre } \\
\text { - Stroke }<6 \text { months not related to a previously documented } \\
\text { PFO or other identifiable cause } \\
\text { - TIA associated with acute brain infarct at DW-MRI or } \\
\text { transient lateralising motor weakness, speech difficulty, } \\
\text { amaurosis fugax or blindness < } 6 \text { months before not related } \\
\text { to a previously documented PFO or other identifiable } \\
\text { cause } \\
\text { - Vascular access from the femoral vein expected to } \\
\text { accommodate the } 10 \text { Fr delivery system } \\
\text { - Critical cardiac structures not expected to come in contact } \\
\text { with the device with approximately } 1 \text { mm of margin } \\
\text { - The size of the PFO must be amenable to selection of a } \\
\text { STARFlex device } \\
\text { - Acquisition of the informed consent }\end{array}$ & $\begin{array}{l}\text { - No right-to-left shunting through a PFO } \\
\text { - Potential source of embolic stroke or TIA other than } \\
\text { PFO (carotid artery stenosis }>50 \% \text { or ulcerated plaque } \\
\text { or association with thrombus; }>50 \% \text { intracranial } \\
\text { stenosis appropriate to patient's symptoms; complex } \\
\text { aortic arch atheroma exhibiting high-risk features for } \\
\text { embolism; aortic arch, carotid artery, or vertebral } \\
\text { artery dissection; mitral or aortic valve stenosis; mitral } \\
\text { or aortic valve vegetations; mitral or aortic valve } \\
\text { calcified annulus; prosthetic heart valves; left } \\
\text { ventricular ejection fraction of }<30 \% \text {; left ventricular } \\
\text { aneurysm; recent anterior wall myocardial infarction }<3 \\
\text { months before the neurological event; chronic atrial } \\
\text { fibrillation; }>2 \text { atrial fibrillation or flutter episodes } \\
\text { lasting }>30 \text { seconds not related to a reversible cause) } \\
\text { - Large, redundant atrial septal aneurysm which cannot } \\
\text { be covered by the STARFlex device without } \\
\text { interference with other intracardiac structures } \\
\text { - Congenital cardiac defects not repaired prior to } \\
\text { enrolment (atrial septal defect, ventricular septal } \\
\text { defect, coarctation of the aorta, patent ductus } \\
\text { arteriosus) } \\
\text { - Thrombus or lumen occlusion between the femoral } \\
\text { vein access site and the right atrium } \\
\text { - Previously implanted atrial septal device } \\
\text { - Echocardiographic evidence of an intra-atrial or } \\
\text { ventricular thrombus } \\
\text { - Current or }<6 \text { months intravenous drug abuse }\end{array}$ \\
\hline
\end{tabular}


- Known active endocarditis or documented bacteraemia

- Active infections requiring current antibiotic therapy

- Serum creatinine $>2.0 \mathrm{mg} / \mathrm{dL}$

-Women with suspected or known pregnancy

- Known hypersensitivity or contraindication to warfarin, aspirin, heparin, and clopidogrel

- Sensitivity to contrast media, which cannot be adequately pre-medicated

- Any medical condition other than index stroke requiring anticoagulation with warfarin

-White blood count of $<3,000$ cells $/ \mathrm{mm}^{3}$

- Platelet count $<100,000$ cells $/ \mathrm{mm}^{3}$ or $>700,000$

cells $/ \mathrm{mm}^{3}$

- Any disorder of platelet function

- Any coagulopathy

- Moderate or high positive titer of antiphospholipid antibodies

- Known vasculitis or neurologic disorder

- Inability to perform a satisfactory Valsalva manoeuvre

- Contraindication to TEE

- Active peptic ulcer or upper gastro-intestinal bleeding $<6$ months

- Current participation to another investigation that has not completed the primary endpoint or that clinically interferes with the current study endpoints

- Permanent pacemaker

- Inferior vena cava filter

- Right ventricle muscle failure

- Pulmonary hypertension

- Severe tricuspid regurgitation

- Cirrhosis or portal hypertension 
- Pulmonary arteriovenous malformations

- Life expectancy <24 months

- Age <60 years old

- Documentation of PFO with or without atrial septal aneurysm and right-to-left shunting at TEE by positive bubble test and/or colour Doppler flow imaging, either spontaneously or with a Valsalva or cough manoeuvre

- Ischaemic stroke verified clinically and neuroradiologically by MRI, CT or angiography in the absence of another identifiable cause

- Symptoms of TIA and neuroradiologically identified intracranial ischaemic lesion in the absence of another identifiable cause

- Clinically and radiologically verified extracranial periphera thromboembolism in the absence of another identifiable cause

- Sufficient recovery from the thromboembolic index event to allow independent daily activities

- Exclusive implantation of an AMPLATZER PFO Occluder device
- Any identifiable cause for the thromboembolic event other than PFO

- Chronic anticoagulant therapy for reason other than paradoxical embolism

- Mural thrombus

- Dilated cardiomyopathy

- Prosthetic heart valve

- Mitral stenosis

- Bacterial and non-bacterial endocarditis

- Cardiac myxoma

- Stherosclerosis of the aorta

- Chronic or paroxysmal atrial fibrillation

- Significant atherosclerosis or dissection of the aorta

- Clinically relevant atherosclerosis and/or dissection of the intra- and extracranial arteries

- Any pre-existing neurological disorder or significant intracranial disease

- Severe central nervous disease

- Significant collagen vascular disease

- Giant cell arteritis

- Vasculitis or systemic necrotising vasculitis

- Hyperviscosity syndromes

- Hypercoagulable states

- Contraindication for chronic oral anticoagulant or antiplatelet therapy

- Severe bleeding disorder <3 months prior to

randomisation

- Known coagulopathy 
- Platelet disorder

- Significant retinopathy

- Significant intracranial disease

- Previous intracranial haemorrhage

- Previous surgical or percutaneous PFO closure

- Drug and/or alcohol abuse $<48$ hours prior to the thromboembolic index event

- Septicaemia or severe localised infection

- Follow-up over the next 5 years not possible

- Inability to obtain the informed consent a

\begin{tabular}{|c|c|c|}
\hline RESPECT & $\begin{array}{l}\text { - Age } 18-60 \text { years old } \\
\text { - Documentation PFO at TEE by positive bubble test at rest } \\
\text { and/or during Valsalva manoeuvre } \\
\text { - Stroke }<270 \text { days without explanation other than } \\
\text { paradoxical embolism, with symptoms persisting } \geq 24 \\
\text { hours or symptoms persisting }<24 \text { hours but cerebral } \\
\text { infarct at MRI or CT }\end{array}$ & $\begin{array}{l}\text { - Stenosis }>50 \% \text { of the intracranial and extracranial } \\
\text { vessels supplying the involved lesion } \\
\text { - Intracardiac thrombus or tumour } \\
\text { - Acute or recent (<6 months) myocardial infarction or } \\
\text { unstable angina } \\
\text { - Left ventricular aneurysm or akinesis } \\
\text { - Mitral valve stenosis or severe mitral regurgitation } \\
\text { irrespective of aetiology } \\
\text { - Aortic valve stenosis with gradient }>40 \text { mmHg or severe } \\
\text { aortic valve regurgitation } \\
\text { - Mitral or aortic valve vegetation or prosthesis } \\
\text { - Aortic arch plaques protruding }>4 \text { mm into the lumen } \\
\text { - Left ventricular dilated cardiomyopathy with LVEF } \\
<35 \% \\
\text { - Other source of right-to-left shunt (atrial septal defect } \\
\text { and/or fenestrated septum, chronic or intermittent } \\
\text { atrial fibrillation/atrial flutter) } \\
\text { - Active endocarditis or other untreated infections } \\
\text { - Kidney, liver or lung failure }\end{array}$ \\
\hline
\end{tabular}


- Sustained elevated systemic blood pressure to $>160 / 90$ $\mathrm{mmHg}$ despite medications

- Sustained glucose levels $>200 \mathrm{mg} / \mathrm{dL}$ and presence of glucose in the urine despite administration of insulin

- Lacunar infarct probably due to intrinsic small vessel as qualifying event

- Arterial dissection as qualifying event

- Signs of progressive neurological dysfunction

- Hypercoagulable state

- Contraindication to aspirin or clopidogrel

- Pregnancy or desire to become pregnant within the next year

- Interference between AMPLATZER PFO Occluder and intracardiac or intravascular structures

- Malignancy or other illness with life expectancy $<2$ years

- No availability for follow-up for the duration of the trial

- Inability to obtain the informed consent

- Age 16-60 years old

- Documented PFO with large shunt $>30$ microbubbles on TTE or TEE, either spontaneous or during provocation manoeuvres, and/or atrial septal aneurysm on TEE with base of aneurysm $\geq 15 \mathrm{~mm}$ and excursion $>10 \mathrm{~mm}$

- Stroke $\leq 6$ months or initial or recurrent retinal ischaemia confirmed by cerebral imaging

- Modified Rankin score $\leq 3$

- Absence of another identifiable cause of stroke or retinal ischaemia on a thorough aetiological work
- Index stroke with possible cause other than PFO

- Atrial septal defect isolated or associated with PFO and significant left-to-right shunt requiring closure

- Previous surgical or endovascular treatments of PFO or atrial septal aneurysm

- Very large or multiperforated atrial septal aneurysm

- Indication for long-term anticoagulant or antiplatelet therapy for another reason

- Contraindication to both antiplatelet drugs and oral anticoagulants

- Presence of thrombus or occlusion between the femoral venous access and the right atrium 
- Inferior vena cava filter

- Severe pulmonary artery hypertension

- Severe liver failure

- Active peptic ulcer

- Proliferative diabetic retinopathy

- History of severe bleeding

- History of bleeding or coagulopathy related to endovascular treatment

- Active infection

- Follow-up impossible or expected poor compliance

- Presence of other medical problems that would either

lead to inability to complete the study or interfere with

the assessment of outcomes

- Known or suspected pregnancy

- Breastfeeding

- Participation in another study

- Inability to obtain the informed consent

\section{Gore REDUCE}

- Age 18-60 years old

- Documented PFO and right-to left shunting, either spontaneous or during Valsalva manoeuvre, by positive bubble test at TEE

- Ischaemic stroke <180 days, verified by a neurologist, without identifiable cause other than PFO

- TIA associated with new brain infarct at imaging $<180$ days, verified by a neurologist, without identifiable cause other than PFO

- Absence of an identifiable source of thromboembolism in the systemic arterial circulation

- Vascular imaging that rules out other potential sources of cerebral thromboembolism (dissection of the aorta or
- Presence of other potential source of cardio-embolism (atrial fibrillation or atrial flutter, prosthetic heart valve, severe native valve disease, left ventricular ejection fraction $<40 \%$, akinesia or severe hypokinesia of ventricular wall motion, intracardiac thrombus, mitral valve stenosis, prior cardiac surgery, other major congenital cardiac abnormality)

- Anatomic criteria identified during the screening evaluation and/or the screening TEE that are unfavourable for successful placement of the GORE ${ }^{\circledR}$ HELEX Septal Occluder / GORE CARDIOFORM Septal Occluder or contraindications for any device placement (inability to accommodate a $10 \mathrm{Fr}$ delivery catheter, need for trans-septal puncture, requirement for 
neck vessels, carotid stenosis $>50 \%$ and/or presence of ulcerated plaques, or intracranial stenosis $>50 \%$ )

- No evidence of hypercoagulable state requiring

anticoagulation

- Willingness and capability of complying with the study protocol requirements, including the specified follow-up period

- Acquisition of the informed consent placement of more than one device, estimated size of PFO too large for successful device placement, likelihood that device would impinge on cardiac structures, likelihood that anatomy would prevent discs from apposing the septal tissue)

- Neurological deficits not due to stroke that may affect the patient's neurologic assessments

- Lacunar stroke syndrome

- Intracranial pathology that makes the patient inappropriate for study participation (brain tumour other than meningioma, arteriovenous malformation, cerebral haemorrhage, cerebral venous sinus thrombosis on CT or MRI, cerebral aneurysm >7 mm)

- Contraindication to study medications

- Chronic anticoagulation therapy that cannot be discontinued

- Known sensitivity to contrast media that cannot be controlled adequately with pre-medication

- Prior myocardial infarction

- Uncontrolled systemic hypertension

- Uncontrolled diabetes mellitus

- Pulmonary hypertension (mean pulmonary artery pressure $>25 \mathrm{mmHg}$ )

- Active autoimmune disease

- Active infection

- Abuse of alcohol and/or drugs

- Pregnancy, lactation or intent on becoming pregnant through next 24 months

- Modified Rankin Scale score $\geq 3$

- Life expectancy of <1 year

- Major surgical procedure <30 days before randomisation 
- Major elective surgical procedure $<30$ days after randomisation or PFO closure

- Current participation in another investigation that has not completed its primary endpoint or that will clinically confound the study endpoints or does not permit subject to participate in other study

- Anatomic or comorbid conditions that could limit the patient's ability to participate in the study or to comply with follow-up requirements, or impact on the scientific soundness of the results

- Need for any concomitant procedure, based on the results of the screening evaluations, during the PFO closure procedure that may confound detection of device-related adverse events

\section{DEFENSE-PFO}

- Age 18-80 years old

- Documented PFO and right-to-left shunting, either spontaneous or during Valsalva manoeuvre, by positive bubble test at TEE and evidence of high-risk features defined as presence of atrial septal aneurysm (dilated segmentary septum protrusion $\geq 15 \mathrm{~mm}$ ) or septum hypermobility (phasic septal excursion $\geq 10 \mathrm{~mm}$ ) or PFO size $\geq 2 \mathrm{~mm}$ during Valsalva manoeuvre.

- Ischaemic stroke <180 days, with symptoms lasting 24 hours or more or was associated with evidence of relevant infarction on magnetic resonance imaging of the brain and exclusion of significant large-artery atherosclerotic disease, established cardioembolic source, small-vessel occlusive disease, hypercoagulable disorder requiring anticoagulation, or arterial dissection.

-Willingness to participate in follow-up visits
- Other source of right-to-left shunt including atrial septal defect and fenestrated septum

- Previous ischaemic stroke due to small-vessel occlusive disease

- Chronic or intermittent atrial fibrillation or flutter

- History of myocardial infarction or unstable angina

- History of intracranial bleeding, confirmed arteriovenous malformation, aneurysm or uncontrolled coagulopathy

- Pre-existing neurological disorder

- Left ventricular systolic dysfunction with aneurysm of akinesia

- Contraindications to TEE

- Contraindications to antiplatelet therapy

- Underlying malignancy

- Pregnancy or desire to become pregnant 
CT: computed tomography; MRI: magnetic resonance imaging; PFO: patent foramen ovale; TEE: transoesophageal echocardiography; TTE: transthoracic echocardiography 
Supplementary Table 4. Main clinical and anatomic characteristics by group.

\begin{tabular}{lcccc} 
& $\begin{array}{c}\text { Total } \\
(\mathrm{n}=3,560)\end{array}$ & $\begin{array}{c}\text { tPFOc } \\
(\mathrm{n}=1,889)\end{array}$ & $\begin{array}{c}\text { ATA } \\
(\mathrm{n}=1,671)\end{array}$ & $p$ \\
\hline Age & $45.3 \pm 9.9$ & $45.3 \pm 9.9$ & $45.4 \pm 9.9$ & 0.764 \\
\hline Male & $55.0(1,958)$ & $54.2(1,024)$ & $55.9(934)$ & 0.313 \\
\hline Diabetes & $5.9(209)$ & $5.6(106)$ & $6.2(103)$ & 0.484 \\
\hline Smoking & $17.4(618)$ & $17.8(337)$ & $16.8(281)$ & 0.421 \\
\hline Hypertension & $26.6(947)$ & $26.9(509)$ & $26.2(438)$ & 0.621 \\
\hline Hypercholesterolaemia & $34.8(1,009)^{\mathrm{a}}$ & $34.8(504)^{\mathrm{a}}$ & $34.8(505)^{\mathrm{a}}$ & 0.933 \\
\hline Index event of stroke & $92.8(3,304)$ & $93.5(1,766)$ & $92.0(1,538)$ & 0.095 \\
\hline Large PFO & $61.7(1,992)^{\mathbf{b}}$ & $62.0(1,070)^{\mathrm{b}}$ & $61.3(922)^{\mathbf{b}}$ & 0.705 \\
\hline Septal aneurysm & $32.0(926)^{\mathrm{c}}$ & $32.2(466)^{\mathrm{c}}$ & $31.7(460)^{\mathrm{c}}$ & 0.791 \\
\hline
\end{tabular}

Data are presented as percentage (number) or mean (standard deviation).

${ }^{a}$ Rates of hypercholesterolaemia are not disclosed/collected in the Gore REDUCE trial ${ }^{13}$, therefore data from this study are not included.

${ }^{\mathrm{b}}$ Available from $93.8 \%(3,227), 94.3 \%(1,726)$, and 93.3\% $(1,503)$ of patients, respectively. Not reported in the DEFENSE-PFO ${ }^{14}$.

${ }^{\mathrm{c}}$ In the Gore REDUCE trial ${ }^{13}$, rates of septal aneurysm were collected only for the PFO closure group, therefore data from this study are not included. 
Supplementary Table 5. Main clinical and anatomic characteristics by trial.

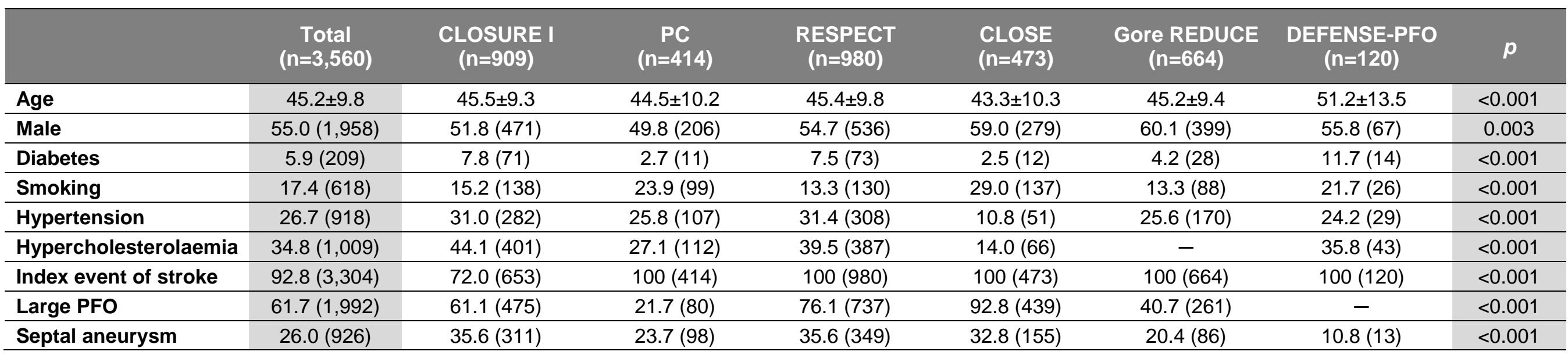

Data are presented as percentage (number) or mean (standard deviation). 
Supplementary Table 6. Antiplatelet and anticoagulant medications in patients assigned to tPFOc and ATA across the included trials.

\begin{tabular}{|c|c|c|c|c|c|c|}
\hline & CLOSURE I & PC & ECT & CLOSE & Gore REDUCE & DEFENSE-PFO \\
\hline $\begin{array}{c}\text { Medications } \\
\text { in the tPFOc } \\
\text { group }\end{array}$ & $\begin{array}{l}\text { Acetylsalicylic acid } 81 \text { - } \\
325 \mathrm{mg} \text { daily for } 2 \text { years } \\
\text { and clopidogrel } 75 \mathrm{mg} \\
\text { daily for } 6 \text { months } \\
\text { [6-month DAPT] }\end{array}$ & $\begin{array}{c}\text { Acetylsalicylic acid } \\
100-325 \mathrm{mg} \text { daily for } \\
5-6 \text { months and } \\
\text { clopidogrel } 75-150 \mathrm{mg} \\
\text { daily for } 1-6 \text { months or } \\
\text { ticlopidine } 250-500 \mathrm{mg} \\
\text { daily for } 1-6 \text { months } \\
\text { [1- to } 6 \text {-month DAPT] }\end{array}$ & $\begin{array}{l}\text { Acetylsalicylic acid } \\
81-325 \mathrm{mg} \text { daily for } \\
6 \text { months }+ \\
\text { clopidogrel } 75 \mathrm{mg} \\
\text { daily for } 1 \text { month } \\
\text { [1-month DAPT] }\end{array}$ & $\begin{array}{c}\text { Acetylsalicylic acid } 75 \\
\text { mg daily for } 3 \text { months } \\
\text { + clopidogrel } 75 \mathrm{mg} \\
\text { daily for } 3 \text { months } \\
\text { [3-month DAPT] } \\
\text { followed by } \\
\text { acetylsalicylic acid or } \\
\text { clopidogrel or } \\
\text { acetylsalicylic acid + } \\
\text { extended-release } \\
\text { dipyridamole }\end{array}$ & $\begin{array}{l}\text { - Acetylsalicylic acid } \\
75-325 \mathrm{mg} \text { daily or } \\
\text { - Clopidogrel } 75 \mathrm{mg} \\
\text { daily or } \\
\text { - Acetylsalicylic acid } \\
50-100 \mathrm{mg} \text { daily + } \\
\text { dipyridamole } 225- \\
400 \mathrm{mg} \text { daily } \\
\text { Patients were } \\
\text { expected to continue } \\
\text { antiplatelet therapy } \\
\text { for the duration of the } \\
\text { follow-up } \\
\text { [ } \geq 2 \text { years of DAPT] }\end{array}$ & $\begin{array}{l}\text { - Acetylsalicylic acid } 100 \\
\text { mg daily + clopidogrel } \\
75 \text { mg daily for at least } \\
6 \text { months } \\
\text { [ } \geq 6 \text {-month DAPT] } \\
\text { At physician's discretion, } \\
\text { patients either stopped } \\
\text { antiplatelet therapy or } \\
\text { took acetylsalicylic acid, or } \\
\text { acetylsalicylic acid and } \\
\text { clopidogrel, or aspirin and } \\
\text { cilostazol } \\
\text { or } \\
\text { - Warfarin } \\
\text { After } 6 \text { months, at } \\
\text { physician's discretion, } \\
\text { patients either stopped } \\
\text { the therapy or } \\
\text { continued oral } \\
\text { anticoagulation. }\end{array}$ \\
\hline $\begin{array}{l}\text { Medications } \\
\text { in the ATA } \\
\text { group }\end{array}$ & $\begin{array}{l}\text { - Acetylsalicylic acid } \\
81-325 \mathrm{mg} \text { daily or } \\
\text { - Clopidogrel } 75 \mathrm{mg} \\
\text { daily or } \\
\text { - Acetylsalicylic acid } \\
81-325 \mathrm{mg} \text { daily + } \\
\text { clopidogrel } 75 \mathrm{mg} \\
\text { daily }\end{array}$ & - Antiplatelet therapy & $\begin{array}{l}\text { - Acetylsalicylic acid } \\
\text { - Warfarin } \\
\text { - Clopidogrel } \\
\text { - Acetylsalicylic acid } \\
\text { + extended-release } \\
\text { dipyridamole } \\
\text { - Acetylsalicylic acid } \\
\text { + clopidogrel }\end{array}$ & $\begin{array}{l}\text { Acetylsalicylic acid } 75 \\
\text { mg daily for } 3 \text { months } \\
\text { + clopidogrel } 75 \mathrm{mg} \\
\text { daily for } 3 \text { months } \\
\text { followed by } \\
\text { acetylsalicylic acid or } \\
\text { clopidogrel or } \\
\text { acetylsalicylic acid + }\end{array}$ & $\begin{array}{l}\text { - Acetylsalicylic acid } \\
75-325 \mathrm{mg} \text { daily or } \\
\text { - Clopidogrel } 75 \mathrm{mg} \\
\text { daily or } \\
\text { - Acetylsalicylic acid } \\
50-100 \mathrm{mg} \text { daily + } \\
\text { dipyridamole } 225- \\
400 \mathrm{mg} \text { daily }\end{array}$ & $\begin{array}{l}\text { - Acetylsalicylic acid } 100 \\
\text { mg daily + clopidogrel } \\
75 \text { mg daily for at least } \\
6 \text { months } \\
\text { [ } \geq 6 \text {-month DAPT] } \\
\text { At physician's discretion, } \\
\text { patients either stopped } \\
\text { antiplatelet therapy or } \\
\text { took acetylsalicylic acid, or }\end{array}$ \\
\hline
\end{tabular}


- Warfarin

After 6 months, at physician's discretion, patients either stopped the therapy or continued oral anticoagulation. 
Supplementary Table 7. Primary endpoints and definitions of stroke across the included trials.

\begin{tabular}{|c|c|c|c|c|c|c|}
\hline & CLOSURE I & PC & RESPECT & CLOSE & Gore REDUCE & DEFENSE-PFO \\
\hline $\begin{array}{l}\text { Primary } \\
\text { endpoint }\end{array}$ & $\begin{array}{l}\text { TIA or ischaemic } \\
\text { stroke }<180 \text { days }\end{array}$ & $\begin{array}{l}\text { TIA with brain } \\
\text { infarct at imaging or } \\
\text { ischaemic stroke or } \\
\text { extra-cranial } \\
\text { embolism }\end{array}$ & $\begin{array}{l}\text { Ischaemic stroke } \\
<270 \text { days }\end{array}$ & $\begin{array}{c}\text { Ischaemic stroke }<180 \\
\text { days }\end{array}$ & $\begin{array}{l}\text { TIA with new brain } \\
\text { infarct at imaging or } \\
\text { ischaemic stroke } \\
<180 \text { days }\end{array}$ & $\begin{array}{l}\text { Ischaemic stroke } \\
<180 \text { days }\end{array}$ \\
\hline $\begin{array}{c}\text { Definition } \\
\text { of } \\
\text { stroke }\end{array}$ & $\begin{array}{l}\text { Acute focal } \\
\text { neurological } \\
\text { event that is } \\
\text { MRI positive, } \\
\text { regardless of } \\
\text { duration of } \\
\text { clinical } \\
\text { symptoms. }\end{array}$ & $\begin{array}{c}\text { Any neurologic } \\
\text { deficit lasting for } \\
>24 \text { hours. } \\
\text { Whenever possible } \\
\text { a head CT/MRI } \\
\text { scan is performed } \\
\text { to differentiate } \\
\text { ischaemic stroke } \\
\text { from haemorrhage. }\end{array}$ & $\begin{array}{c}\text { Acute focal } \\
\text { neurological deficit } \\
\text { presumed to be due to } \\
\text { focal ischaemia and } \\
\text { either symptoms } \\
\text { persisting } \geq 24 \text { hours or } \\
\text { symptoms persisting } \\
<24 \text { hours but } \\
\text { associated with MRI or } \\
\text { CT findings of a new, } \\
\text { neuroanatomically } \\
\text { relevant, cerebral } \\
\text { infarct. }\end{array}$ & $\begin{array}{l}\text { Sudden onset of focal } \\
\text { neurological symptoms } \\
\text { either lasting }>24 \text { hours } \\
\text { with no apparent cause } \\
\text { other than cerebral } \\
\text { ischaemia or } \\
\text { associated with the } \\
\text { presence of cerebral } \\
\text { infarction in the } \\
\text { appropriate territory on } \\
\text { brain imaging (CT or } \\
\text { MRI), regardless of the } \\
\text { duration of symptoms. }\end{array}$ & $\begin{array}{l}\text { Clinical symptoms } \\
\text { lasting } \geq 24 \text { hours } \\
\text { associated with } \\
\text { evidence of brain } \\
\text { infarction on MRI } \\
\text { or CT }\end{array}$ & $\begin{array}{c}\text { Clinical symptoms } \\
\text { lasting } \geq 24 \text { hours } \\
\text { or evidence of } \\
\text { brain infarction on } \\
\text { MRI }\end{array}$ \\
\hline
\end{tabular}


Supplementary Table 8. Ischaemic stroke across trials and follow-up time points.

\begin{tabular}{|c|c|c|c|c|c|c|}
\hline & \multicolumn{2}{|c|}{ Events } & \multicolumn{2}{|c|}{ Events / 100 person-years } & \multicolumn{2}{|c|}{$\begin{array}{l}\text { Kaplan-Meier } \\
\text { estimates (\%) }\end{array}$} \\
\hline & tPFOc & ATA & tPFOc & ATA & tPFOc & ATA \\
\hline \multicolumn{7}{|l|}{ CLOSURE I } \\
\hline - 2 Years & 12 & 13 & 1.43 & 1.60 & 2.9 & 3.1 \\
\hline \multicolumn{7}{|l|}{ PC } \\
\hline $\begin{array}{l}\text { - } 2 \text { Years } \\
\text { - } 5 \text { Years/Longest Follow-Up }\end{array}$ & $\begin{array}{l}\bullet \\
\bullet \\
\bullet\end{array}$ & $\begin{array}{l}\bullet 4 \\
\bullet 7\end{array}$ & $\begin{array}{l}\bullet 0.26 \\
\bullet 0.12 \\
\end{array}$ & $\begin{array}{l}\bullet 1.05 \\
\bullet 0.86 \\
\end{array}$ & 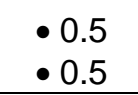 & 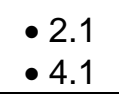 \\
\hline \multicolumn{7}{|l|}{ RESPECT } \\
\hline $\begin{array}{l}\text { - } 2 \text { Years } \\
\text { - } 5 \text { Years } \\
\text { - Longest Follow-Up }\end{array}$ & $\begin{array}{l}\cdot 8 \\
\cdot 12 \\
\cdot 18 \\
\end{array}$ & $\begin{array}{l}\cdot 14 \\
\cdot 21 \\
\cdot 28 \\
\end{array}$ & $\begin{array}{l}\bullet 0.84 \\
\bullet 0.54 \\
-0.58\end{array}$ & $\begin{array}{l}-1.61 \\
-1.08 \\
-1.07 \\
\end{array}$ & $\begin{array}{l}-1.6 \\
-2.6 \\
-4.9 \\
\end{array}$ & $\begin{array}{l}\cdot 3.1 \\
\bullet 4.9 \\
\cdot 11.6 \\
\end{array}$ \\
\hline \multicolumn{7}{|l|}{ CLOSE } \\
\hline $\begin{array}{l}\text { - } 2 \text { Years } \\
\text { - } 5 \text { Years } \\
\text { - Longest Follow-Up }\end{array}$ & $\begin{array}{l}\cdot 0 \\
\cdot 0 \\
-0 \\
\end{array}$ & $\begin{array}{l}-8 \\
\text { - } 11 \\
\text { - } 14 \\
\end{array}$ & $\begin{array}{l}-0 \\
-0 \\
-0 \\
\end{array}$ & $\begin{array}{l}\bullet 1.75 \\
\bullet 1.11 \\
-1.13 \\
\end{array}$ & $\begin{array}{l}\cdot 0 \\
-0 \\
-0 \\
\end{array}$ & $\begin{array}{l}-3.4 \\
-4.9 \\
-8.1 \\
\end{array}$ \\
\hline \multicolumn{7}{|l|}{ Gore REDUCE } \\
\hline $\begin{array}{l}\text { - } 2 \text { Years } \\
\text { - } 5 \text { Years/Longest Follow-Up }\end{array}$ & $\begin{array}{l}\bullet 5 \\
\bullet 6\end{array}$ & $\begin{array}{l}\cdot 10 \\
\bullet 12\end{array}$ & $\begin{array}{l}\bullet 0.60 \\
\bullet 0.39\end{array}$ & $\begin{array}{l}\bullet 2.55 \\
\bullet 1.71\end{array}$ & $\begin{array}{l}\bullet \\
\bullet \\
\bullet\end{array} 1.6$ & $\begin{array}{l}\bullet 4.7 \\
\bullet \\
-5.9\end{array}$ \\
\hline \multicolumn{7}{|l|}{ DEFENSE-PFO } \\
\hline - 2 Years & 0 & 5 & 0 & 5.38 & 0 & 10.5 \\
\hline $\begin{array}{l}\text { Total } \\
\text { - } 2 \text { Years } \\
\text { - } 5 \text { Years } \\
\text { - Longest Follow-Up }\end{array}$ & $\begin{array}{l}\cdot 26 \\
\cdot 31 \\
\cdot 37 \\
\end{array}$ & $\begin{array}{l}\cdot 54 \\
\cdot 69 \\
\cdot 79\end{array}$ & $\begin{array}{l}\cdot 0.73 \\
\cdot 0.47 \\
\cdot 0.48 \\
\end{array}$ & $\begin{array}{l}-1.84 \\
-1.31 \\
-1.26\end{array}$ & $\begin{array}{l}-1.4 \\
-2.0 \\
-3.6\end{array}$ & $\begin{array}{l}\cdot 3.5 \\
\cdot 5.2 \\
\cdot 12.0 \\
\end{array}$ \\
\hline
\end{tabular}

All trials were included. 
Supplementary Table 9. Main adverse cardiovascular events other than atrial fibrillation and major bleeding across the included trials.

\begin{tabular}{|c|c|c|c|c|c|c|}
\hline tPFOc vs. ATA & CLOSURE I & PC & RESPECT & CLOSE & Gore REDUCE & DEFENSE-PFO \\
\hline Procedural complications & - & $1.5(3)$ & $2.4(12)$ & $5.9(14)$ & $2.5(11)$ & - \\
\hline Device-related complications & - & 0 & $2.6(13)$ & - & $1.4(6)$ & - \\
\hline Erosion of cardiac structures & - & - & - & - & 0 & - \\
\hline Vascular complications & $3.2(13)$ & $1.0(2)$ & $0.6(3)$ & $0.8(2) / 0$ & $1.0(4)$ & - \\
\hline Any adverse event & - & $34.8(71) / 29.5(62)$ & - & - & $\mathrm{cos}$ & - \\
\hline Any serious adverse event & $16.9(68) / 16.6(76)$ & $21.1(43) / 17.6(37)$ & $40.3(201) / 36.0(173)$ & $35.7(85) / 33.2(78)$ & $23.1(102) / 27.8(62)$ & - \\
\hline Any minor adverse event & - & $19.6(40) / 20.0(42)$ & - & - & - & - \\
\hline Any bleeding & - & $3.0(8) / 5.7(12)$ & $2.2(11) / 1.0(5)$ & - & - & - \\
\hline Syncope & $0 / 0.5(2)$ & $1.0(2) / 0.5(1)$ & $0.6(3) / 1.0(5)$ & $0 / 0$ & - & - \\
\hline Dyspnoea & - & $0 / 1.9(4)$ & $0.6(3) / 0.2(1)$ & $0.4(1) / 0$ & - & - \\
\hline Chest pain/discomfort & - & $1.5(3) / 1.9(4)$ & $3.6(18) / 3.1(15)$ & $0.8(2) / 0$ & $0.4(2) / 0$ & - \\
\hline Pulmonary embolism & - & - & $2.4(12) / 0.6(3)$ & $0.4(1) / 0$ & $0.5(2) / 0.4(1)$ & - \\
\hline Coronary embolism & - & - & -2 & $0.8(2) / 0$ & - & - \\
\hline Systemic embolism & - & 0 vs. 0 & - & - & $0 / 0$ & - \\
\hline
\end{tabular}

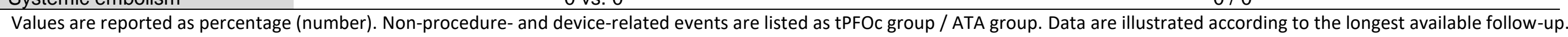


Supplementary Table 10. Evaluation according to GRADE of the overall reliability of the conclusions provided.

\begin{tabular}{|c|c|c|c|c|c|c|}
\hline \multicolumn{6}{|c|}{ Quality assessment } & \multirow{2}{*}{$\begin{array}{l}\text { Overall } \\
\text { quality }\end{array}$} \\
\hline Trials & Study design & Risk of bias & Inconsistency & Indirectness & Imprecision & \\
\hline \multicolumn{7}{|l|}{ Stroke } \\
\hline 6 & Randomised trials & Not serious & Serious & Not serious & Not serious & $\begin{array}{l}\bigoplus \bigoplus \bigoplus \bigcirc \\
\text { MODERATE }\end{array}$ \\
\hline \multicolumn{7}{|l|}{ TIA } \\
\hline 6 & Randomised trials & Not serious & Not serious & Not serious & Not serious & $\underset{\mathrm{HIGH}}{\oplus \bigoplus \bigoplus \bigoplus \bigoplus}$ \\
\hline \multicolumn{7}{|c|}{ Atrial fibrillation } \\
\hline 5 & Randomised trials & Not serious & Not serious & Not serious & Not serious & $\underset{\text { HIGH }}{\bigoplus \bigoplus \bigoplus \bigoplus}$ \\
\hline \multicolumn{7}{|c|}{ Major bleeding } \\
\hline 5 & Randomised trials & Not serious & Not serious & Not serious & Not serious & $\underset{\text { HIGH }}{\bigoplus \bigoplus \bigoplus \bigoplus}$ \\
\hline \multicolumn{7}{|l|}{ Migraine } \\
\hline 5 & Randomised trials & Serious & Not serious & Serious & Not serious & 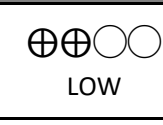 \\
\hline
\end{tabular}




\section{References}

1. Lechat P, Mas JL, Lascault G, Loron P, Theard M, Klimczac M, Drobinski G, Thomas D, Grosgogeat Y. Prevalence of patent foramen ovale in patients with stroke. N Engl J Med. 1988;318:1148-52.

2. Kutty S, Sengupta PP, Khandheria BK. Patent foramen ovale: the known and the to be known. J Am Coll Cardiol. 2012;59:1665-71.

3. Pavlovic M, Buellesfeld L, Meier B. Tools \& techniques: PFO/ASD closure. Eurolntervention. 2011;7:408-10.

4. Kent DM, Dahabreh IJ, Ruthazer R, Furlan AJ, Reisman M, Carroll JD, Saver JL, Smalling RW, Jüni P, Mattle HP, Meier B, Thaler DE. Device Closure of Patent Foramen Ovale After Stroke: Pooled Analysis of Completed Randomized Trials. J Am Coll Cardiol. 2016;67:907-17.

5. Furlan AJ, Reisman M, Massaro J, Mauri L, Adams H, Albers GW, Felberg R, Herrmann H, Kar S, Landzberg M, Raizner A, Wechsler L; CLOSURE I Investigators. Closure or medical therapy for cryptogenic stroke with patent foramen ovale. N Engl J Med. 2012;366:991-9.

6. Meier B, Kalesan B, Mattle HP, Khattab AA, Hildick-Smith D, Dudek D, Andersen G, Ibrahim R, Schuler G, Walton AS, Wahl A, Windecker S, Jüni P; PC Trial Investigators. Percutaneous closure of patent foramen ovale in cryptogenic embolism. N Engl J Med. 2013;368:1083-91.

7. Carroll JD, Saver JL, Thaler DE, Smalling RW, Berry S, MacDonald LA, Marks DS, Tirschwell DL; RESPECT Investigators. Closure of patent foramen ovale versus medical therapy after cryptogenic stroke. N Engl J Med. 2013;368:1092-100.

8. Wahl A, Jüni P, Mono ML, Kalesan B, Praz F, Geister L, Raber L, Nedeltchev K, Mattle HP, Windecker S, Meier B. Long-term propensity score-matched comparison of percutaneous closure 
of patent foramen ovale with medical treatment after paradoxical embolism. Circulation.

2012;125:803-12.

9. Inglessis I, Elmariah S, Rengifo-Moreno PA, Margey R, O'Callaghan C, Cruz-Gonzalez I, Baron S, Mehrotra P, Tan TC, Hung J, Demirjian ZN, Buonanno FS, Ning M, Silverman SB, Cubeddu RJ, Pomerantsev E, Schainfeld RM, Dec GW Jr, Palacios IF. Long-term experience and outcomes with transcatheter closure of patent foramen ovale. JACC Cardiovasc Interv. 2013;6:1176-83.

10. European Stroke Organisation (ESO) Executive Committee; ESO Writing Committee. Guidelines for management of ischaemic stroke and transient ischaemic attack 2008. Cerebrovasc Dis. 2008;25:457-507.

11. Kernan WN, Ovbiagele B, Black HR, Bravata DM, Chimowitz MI, Ezekowitz MD, Fang MC, Fisher M, Furie KL, Heck DV, Johnston SC, Kasner SE, Kittner SJ, Mitchell PH, Rich MW, Richardson D, Schwamm LH, Wilson JA; American Heart Association Stroke Council, Council on Cardiovascular and Stroke Nursing, Council on Clinical Cardiology, and Council on Peripheral Vascular Disease. Guidelines for the prevention of stroke in patients with stroke and transient ischemic attack: a guideline for healthcare professionals from the American Heart Association/American Stroke Association. Stroke. 2014;45:2160-236.

12. Mas JL, Derumeaux G, Guillon B, Massardier E, Hosseini H, Mechtouff L, Arquizan C, Béjot $Y$, Vuillier F, Detante O, Guidoux C, Canaple S, Vaduva C, Dequatre-Ponchelle N, Sibon I, Garnier P, Ferrier A, Timsit S, Robinet-Borgomano E, Sablot D, Lacour JC, Zuber M, Favrole P, Pinel JF, Apoil M, Reiner P, Lefebvre C, Guérin P, Piot C, Rossi R, Dubois-Randé JL, Eicher JC, Meneveau N, Lusson JR, Bertrand B, Schleich JM, Godart F, Thambo JB, Leborgne L, Michel P, Pierard L, Turc G, Barthelet M, Charles-Nelson A, Weimar C, Moulin T, Juliard JM, Chatellier G; CLOSE Investigators. 
Patent Foramen Ovale Closure or Anticoagulation vs. Antiplatelets after Stroke. N Engl J Med. 2017;377:1011-21.

13. Søndergaard L, Kasner SE, Rhodes JF, Andersen G, Iversen HK, Nielsen-Kudsk JE, Settergren M, Sjostrand C, Roine RO, Hildick-Smith D, Spence JD, Thomassen L; Gore REDUCE Clinical Study Investigators. Patent Foramen Ovale Closure or Antiplatelet Therapy for Cryptogenic Stroke. N Engl J Med. 2017;377:1033-42.

14. Lee PH, Song JK, Kim JS, Heo R, Lee S, Kim DH, Song JM, Kang DH, Kwon SU, Kang DW, Lee D, Kwon HS, Yun SC, Sun BJ, Park JH, Lee JH, Jeong HS, Song HJ, Kim J, Park SJ. Cryptogenic Stroke and High-Risk Patent Foramen Ovale: The DEFENSE-PFO Trial. J Am Coll Cardiol. 2018;71:2335-42.

15. Capodanno D, Milazzo G, Vitale L, Di Stefano D, Di Salvo M, Grasso C, Tamburino C. Updating the evidence on patent foramen ovale closure versus medical therapy in patients with cryptogenic stroke: a systematic review and comprehensive meta-analysis of 2,303 patients from three randomised trials and 2,231 patients from 11 observational studies. Eurolntervention. 2014;9:1342-9.

16. Stortecky S, da Costa BR, Mattle HP, Carroll J, Hornung M, Sievert H, Trelle S, Windecker S, Meier B, Jüni P. Percutaneous closure of patent foramen ovale in patients with cryptogenic embolism: a network meta-analysis. Eur Heart J. 2015;36:120-8.

17. Vaduganathan M, Qamar A, Gupta A, Bajaj N, Golwala HB, Pandey A, Bhatt DL. Patent Foramen Ovale Closure for Secondary Prevention of Cryptogenic Stroke: Updated Meta-Analysis of Randomized Clinical Trials. Am J Med. 2018;131:575-7.

18. De Rosa S, Sievert H, Sabatino J, Polimeni A, Sorrentino S, Indolfi C. Percutaneous Closure Versus Medical Treatment in Stroke Patients With Patent Foramen Ovale: A Systematic Review and Meta-analysis. Ann Intern Med. 2018;168:343-50. 
19. Shah R, Nayyar M, Jovin IS, Rashid A, Bondy BR, Fan TM, Flaherty MP, Rao SV. Device Closure Versus Medical Therapy Alone for Patent Foramen Ovale in Patients With Cryptogenic Stroke: A Systematic Review and Meta-analysis. Ann Intern Med. 2018;168:335-42.

20. Liberati A, Altman DG, Tetzlaff J, Mulrow C, Gotzsche PC, loannidis JP, Clarke M, Devereaux PJ, Kleijnen J, Moher D. The PRISMA statement for reporting systematic reviews and metaanalyses of studies that evaluate healthcare interventions: explanation and elaboration. BMJ. 2009;339:b2700.

21. Higgins J, Green S. Cochrane Handbook for Systematic Reviews of Interventions 5.2.0 [Updated June 2017]. www.handbookcochrane.org . Last accessed 15 November 2017.

22. Borenstein M, Hedges LV, Higgins JPT, Rothstein HR. Introduction to Meta-Analysis. West Sussex, United Kingdom: John Wiley \& Sons; 2009.

23. Altman DG, Andersen PK. Calculating the number needed to treat for trials where the outcome is time to an event. BMJ. 1999;319:1492-5.

24. Higgins JP, Thompson SG, Deeks JJ, Altman DG. Measuring inconsistency in meta-analyses. BMJ. 2003;327:557-60.

25. Guyot P, Ades AE, Ouwens MJ, Welton NJ. Enhanced secondary analysis of survival data: reconstructing the data from published Kaplan-Meier survival curves. BMC Med Res Methodol. 2012;12:9.

26. Giacoppo D, Colleran R, Cassese S, Frangieh AH, Wiebe J, Joner M, Schunkert H, Kastrati A, Byrne RA. Percutaneous Coronary Intervention vs Coronary Artery Bypass Grafting in Patients With Left Main Coronary Artery Stenosis: A Systematic Review and Meta-analysis. JAMA Cardiol. 2017;2:1079-88. 
27. Therneau TM, Grambsch PM. Modeling Survival Data: Extending the Cox Model. New York: Springer-Verlag; 2000.

28. Riley RD, Jackson D, Salanti G, Burke DL, Price M, Kirkham J, White IR. Multivariate and network meta-analysis of multiple outcomes and multiple treatments; rationale, concepts, and examples. BMJ. 2017;358:j3932.

29. Viechtbauer W, Cheung MW. Outlier and influence diagnostics for meta-analysis. Res Synth Meth. 2010;1:112-25.

30. Miladinovic B, Hozo I, Djulbegovic B. Trial sequential boundaries for cumulative metaanalyses. Stata J. 2013;13:77-91.

31. Schünemann H, Brozek J, Guyatt G, Oxman A. Handbook for grading the quality of evidence and the strength of recommendations using the GRADE approach. https://gdt.gradepro.org/app/handbook/handbook.html . Last accessed 15 November 2017.

32. Saver JL, Carroll JD, Thaler DE, Smalling RW, MacDonald LA, Marks DS, Tirschwell DL; RESPECT Investigators. Long-Term Outcomes of Patent Foramen Ovale Closure or Medical Therapy after Stroke. N Engl J Med. 2017;377:1022-32.

33. Price MJ. Transcatheter Closure of Patent Foramen Ovale: Devices and Technique. Interv Cardiol Clin. 2017;6:555-67.

34. Hornung M, Bertog SC, Franke J, Id D, Taaffe M, Wunderlich N, Vaskelyte L, Hofmann I, Sievert $\mathrm{H}$. Long-term results of a randomized trial comparing three different devices for percutaneous closure of a patent foramen ovale. Eur Heart J. 2013;34:3362-9.

35. Kent DM, Dahabreh IJ, Ruthazer R, Furlan AJ, Weimar C, Serena J, Meier B, Mattle HP, Di Angelantonio E, Paciaroni M, Schuchlenz H, Homma S, Lutz JS, Thaler DE. Anticoagulant vs. 
antiplatelet therapy in patients with cryptogenic stroke and patent foramen ovale: an individual participant data meta-analysis. Eur Heart J. 2015;36:2381-9.

36. Hara H, Virmani R, Ladich E, Mackey-Bojack S, Titus J, Reisman M, Gray W, Nakamura M, Mooney M, Poulose A, Schwartz RS. Patent foramen ovale: current pathology, pathophysiology, and clinical status. J Am Coll Cardiol. 2005;46:1768-76.

37. Mennuni MG, Halperin JL, Bansilal S, Schoos MM, Theodoropoulos KN, Meelu OA, Sartori S, Giacoppo D, Bernelli C, Moreno PR, Krishnan P, Baber U, Lucarelli C, Dangas GD, Sharma SK, Kini AS, Tamburino C, Chieffo A, Colombo A, Presbitero P, Mehran R. Balancing the Risk of Bleeding and Stroke in Patients With Atrial Fibrillation After Percutaneous Coronary Intervention (from the AVIATOR Registry). Am J Cardiol. 2015;116:37-42.

38. Mattle HP, Evers S, Hildick-Smith D, Becker WJ, Baumgartner H, Chataway J, Gawel M, Göbel H, Heinze A, Horlick E, Malik I, Ray S, Zermansky A, Findling O, Windecker S, Meier B. Percutaneous closure of patent foramen ovale in migraine with aura, a randomized controlled trial. Eur Heart J. 2016;37:2029-2036.

39. Furlan AJ, Reisman M, Massaro J, Mauri L, Adams H, Albers GW, Felberg R, Herrmann H, Kar S, Landzberg M, Raizner A, Wechsler L; CLOSURE I Investigators. Study design of the CLOSURE I Trial: a prospective, multicenter, randomized, controlled trial to evaluate the safety and efficacy of the STARFlex septal closure system versus best medical therapy in patients with stroke or transient ischemic attack due to presumed paradoxical embolism through a patent foramen ovale. Stroke. 2010;41:2872-83.

40. Furlan AJ; CLOSURE I Investigators. PFO Closure: CLOSURE. Stroke. 2013;44:S45-7.

41. Khattab AA, Windecker S, Jüni P, Hildick-Smith D, Dudek D, Andersen HR, Ibrahim R, Schuler G, Walton AS, Wahl A, Mattle HP, Meier B. Randomized clinical trial comparing 
percutaneous closure of patent foramen ovale (PFO) using the Amplatzer PFO Occluder with medical treatment in patients with cryptogenic embolism (PC-Trial): rationale and design. Trials. 2011;12:56.

42. Kaplan EL, Meier P. Nonparametric Estimation from Incomplete Observations. J Am Stat Assoc. 1958;53:457-481.

43. Grambsch P, Therneau T. Proportional hazards tests and diagnostics based on weighted residuals. Biometrika. 1994;81:515-26.

44. Firth D. Bias reduction of maximum likelihood estimates. Biometrika. 1993;80:27-38.

45. Parmar MK, Torri V, Stewart L. Extracting summary statistics to perform meta-analyses of the published literature for survival endpoints. Stat Med. 1998;17:2815-34.

46. Sweeting MJ, Sutton AJ, Lambert PC. What to add to nothing? Use and avoidance of continuity corrections in meta-analysis of sparse data. Stat Med. 2004;23:1351-75. 